Assurances et gestion des risques

Insurance and Risk Management

\title{
A Comparison of Automobile Insurance Regimes in Canada
}

\section{Rose Anne Devlin}

Volume 86, numéro 1-2, juin 2019

URI : https://id.erudit.org/iderudit/1062464ar

DOI : https://doi.org/10.7202/1062464ar

Aller au sommaire du numéro

\section{Éditeur(s)}

Faculté des sciences de l'administration, Université Laval

ISSN

1705-7299 (imprimé)

2371-4913 (numérique)

Découvrir la revue

Citer ce document

Devlin, R. A. (2019). A Comparison of Automobile Insurance Regimes in Canada. Assurances et gestion des risques / Insurance and Risk Management, 86(1-2), 55-96. https://doi.org/10.7202/1062464ar

\section{Résumé de l'article}

This article compares and contrasts automobile insurance provisions across Canadian jurisdictions, with particular emphasis on comparing how British Columbia (BC) fares relative to other provinces. A brief discussion of the different automobile insurance regimes is provided, as well as the mandated packages in each province. Price quotes are obtained by jurisdiction for the mandated package as well as for enhanced packages, for a hypothetical driver (either male of female) with a driving record that is good or poor, who is 45 years of age and drives a Honda Civic. We find that prices in Vancouver, $\mathrm{BC}$ are in the middle of the pack, and are much lower than in Toronto, Ontario for a driver with a good record. BC average prices are similar to those in Saskatchewan and Manitoba. Loss ratios vary quite a bit over the period 2011-2015, with no clear pattern except that they are always higher in public regimes than private ones. Because these ratios fluctuate from year to year, no one single province has performed consistently or significantly better than the others. One must be very careful when drawing hard and fast conclusions because of the differences in insurance packages across provinces and the aggregated and limited nature of much of the available data. Four conclusions are notable: (i) Automobile prices charged in $\mathrm{BC}$ are in line with those of Manitoba, (ii) a driver in Vancouver pays significantly less than an otherwise comparable driver in Toronto, (iii) in the private system, Ontario has the lowest loss ratios while, in the public system, there is no discernable, stable, relationship across the jurisdictions, and (iv) average claim costs cannot be compared across regimes.
Tous droits réservés $\odot$ Faculté des sciences de l'administration, Université Laval, 2019
Ce document est protégé par la loi sur le droit d'auteur. L'utilisation des services d'Érudit (y compris la reproduction) est assujettie à sa politique d'utilisation que vous pouvez consulter en ligne.

https://apropos.erudit.org/fr/usagers/politique-dutilisation/ 


\section{A COMPARISON OF AUTOMOBILE INSURANCE REGIMES IN CANADA}

Rose Anne DEVLIN1, University of Ottawa

\section{ABSTRACT}

This article compares and contrasts automobile insurance provisions across Canadian jurisdictions, with particular emphasis on comparing how British Columbia (BC) fares relative to other provinces. A brief discussion of the different automobile insurance regimes is provided, as well as the mandated packages in each province. Price quotes are obtained by jurisdiction for the mandated package as well as for enhanced packages, for a hypothetical driver (either male of female) with a driving record that is good or poor, who is 45 years of age and drives a Honda Civic. We find that prices in Vancouver, $\mathrm{BC}$ are in the middle of the pack, and are much lower than in Toronto, Ontario for a driver with a good record. BC average prices are similar to those in Saskatchewan and Manitoba. Loss ratios vary quite a bit over the period 2011-2015, with no clear pattern except that they are always higher in public regimes than private ones. Because these ratios fluctuate from year to year, no one single province has performed consistently or significantly better than the others. One must be very careful when drawing hard and fast conclusions because of the differences in insurance packages across provinces and the aggregated and limited nature of much of the available data. Four conclusions are notable: (i) Automobile prices charged in $\mathrm{BC}$ are in line with those of Manitoba, (ii) a driver in Vancouver pays significantly less than an otherwise comparable driver in Toronto, (iii) in the private system, Ontario has the lowest loss ratios while, in the public system, there is no discernable, stable, relationship across the jurisdictions, and (iv) average claim costs cannot be compared across regimes. 


\section{INTRODUCTION}

This article compares and contrasts automobile insurance provisions across Canadian jurisdictions, with a particular emphasis on British Columbia (BC). A brief discussion of the different automobile insurance regimes in Canada is provided, as well as the mandated packages in each province.

Good data are very difficult to obtain in any one jurisdiction let alone across all of the provinces in Canada. Several compromises had to be made. For instance, the Quebec data were simply not comparable to the other jurisdictions on several fronts, and hence had to be eliminated. Data from the General Insurance Statistical Agency (GISA) has been used for the six provinces with private automobile insurance regimes and these data were only available from 2011 to 2015. These data are reasonably comparable across these provinces but obtaining comparable data from the public provinces was complicated. In this respect, caution has to be taken throughout this report.

Insurance prices were obtained largely through a price-quote agency, as well as through direct contact with various firms. There was no attempt to put any particular regime in a better light than others. After much thought and several preliminary investigations, it was decided to let the representative driver be a reasonably average one- 45 years of age, driving a Honda Civic, employed, yielding price quotes that are indicative of what one would be facing in the different provinces.

This article is structured as follows. It starts with a review of the compulsory insurance packages mandated in each regime. While the list of benefits accompanying these packages is very similar, quite a bit of variation is seen in the details of these benefits across provinces. This review groups provinces as liability or no-fault regimes, and as private and public provision. The next section provides data on the price of automobile insurance by province (except Quebec). Quotes were obtained from a variety of companies, especially in the private regimes. Huge variations were found in prices. When comparing someone living in Toronto to the same person in Vancouver, a good driving record resulted in a much lower price in $\mathrm{BC}$ than in Ontario. The third section compares costs across public and private regimes. Intra-regime comparisons are much more reliable than inter-regime ones. That being said, private regimes had lower loss ratios in general when compared to public ones. The $\mathrm{BC}$ regime is reasonably comparable to the other two public systems in this regard. It is not possible to compare average claim costs across public and private regimes because, among other 
reasons, of the way in which claims are counted. A fourth section examines some of the factors influencing demand for insurance, especially the number of registered vehicles per capita on the road. Alberta and Saskatchewan stand out as having the highest and second highest number, respectively. $\mathrm{BC}$ is in the middle of the pack.

There is a slight upward trend across the board in this number. Fatal accidents per registered vehicle, displays an overall downward trend. Finally, a few words are added about the public versus private provision debate. Overall, there is remarkably little empirical work done on this issue, with one serious undertaking for Canada done in 1976. Not surprisingly, there is no clear cut answer as to which regime is better: the public regime is likely to reap economies of scale and hence have lower costs, but the private one is likely to provide a larger range of products. A few overall conclusions are discussed in the last section.

\section{A Brief ReVIeW of Automobile Insurance in Canadian Provinces}

A minimum level of automobile insurance coverage is mandated and compulsory in every jurisdiction in Canada. Automobile insurance regimes can be described as being based primarily upon liability-based or no-fault-based rules, and can be described as being publicly or privately provided. Six provinces have purely private provision (subject always to public regulations), and four have public monopoly provision (they are really 'hybrid' systems insofar as private companies can provide insurance beyond the basic mandated package; Quebec is an outlier insofar as it has publicly provided insurance for bodily injuries, and privately provided insurance for property damages).

Each province mandates the minimum requirements for an automobile insurance policy. These are described in the Appendix tables A1: table A1a details the requirements in the private provinces and table A1b details the same for the public provinces. While the list of benefits provided in all jurisdictions is more or less the same, there are differences across the regimes in terms of amounts and details. Tables A1a and $b$ reveal, for instance, differences in the amount of medical care provided in the event of an accident, death and survivor benefits, and income replacement rules, across the jurisdictions. It is important to look at the significant differences across provinces in terms of the minimum or basic insurance package, because these will affect the minimum price of insurance. 


\section{a) Liability-Based Vs No-Fault-Based Automobile Insurance Regimes}

Under a liability regime, damages incurred by not-at-fault victims of accidents are recovered from at-fault drivers; drivers thus take out third-party liability insurance to cover these costs in the event of an at-fault accident. Tables A1a and A1b reveal that all provincial jurisdictions in Canada mandate third-party coverage. If an insurance package were comprised only of third-party liability provisions, then those who suffered losses as a result of the fault of others, would be entitled to compensation by the at fault drivers, but the at-fault drivers would not receive any indemnification for own injuries or damages. But this does not describe the situation in Canadian provinces. All automobile insurance regimes in Canada except for Newfoundland and Labrador where it is optional, require some first-party coverage that compensates for 'own' (first party) losses irrespective of fault. Some commentators describe regimes with such first party coverage as 'no fault' ones, but normally to be classified as a 'no- fault' regime, there are restrictions on the right to sue the at-fault driver for damages incurred.

All private insurance regimes have restrictions on the amount of money that can be awarded by the courts for pain and suffering, as indicated in table A1a. Those provinces that have maximum awards for pain and suffering for minor injuries, namely Alberta, New Brunswick, Nova Scotia, Prince Edward Island and Newfoundland and Labrador, are not usually considered as no-fault jurisdictions. Ontario, which limits the right to sue for pain and suffering to injuries that are deemed to be 'severe', is considered to be a 'partial' no-fault regime.

Of the four public insurance provinces, three have no-fault regimes. Manitoba and Quebec do not allow any suits for pain and suffering, and Saskatchewan imposes a $\$ 5,000$ deductible on awards for pain and suffering (since 2003, Saskatchewan has allowed drivers to opt out of no-fault provisions, but this is rarely done). Manitoba and Saskatchewan would be considered as 'partial' no-fault regimes as the right to sue for economic losses in excess of no- fault benefits is maintained. By contrast, Quebec has a pure no-fault system for all road accidents involving bodily injuries. This means that Quebecers cannot resort to the tort system to sue for additional damage recovery.

The point of this brief overview is to highlight the main similarities and differences across provincial jurisdictions with the view to identifying where problems may arise when comparing provincial automobile insurance plans, especially with respect to prices and financial 
outcomes. One expects big differences to exist across public and private regimes, and liability and no-fault ones. I will expand upon some of the intricacies of these differences as needed below. I now turn to a discussion of the price of automobile insurance in each jurisdiction. In order to compare across provincial jurisdictions, quotes were obtained for several different driver profiles. The following section presents this information.

\section{The Price of Auto Insurance across Provinces}

Insurance prices depend upon a variety of factors which may differ across provincial jurisdictions. Table A2 in the Appendix lists these factors, including: type of vehicle; place of residence; driving record; use of vehicle; sex; age; and marital status. These latter three 'personal' criteria are regularly criticized as being 'discriminatory'. Whereas statistically, young, single, males have more accidents, the argument is often raised that individuals should not be judged ex ante based on statistical averages. The public provinces do not price based on age or sex.

As indicated in table A2, many factors are taken into account when pricing insurance. For the purposes of this report, estimates were obtained for the price of insurance for a man and for a woman with the following characteristics: 45 years old, single, employed, driving to work 15 kilometers, annual driving of 15,000 kilometers, 2008 Honda Civic ( 4 door, DX model), living in a city (the most populous city in the province, as specified in the table). This price was obtained

for someone with a 'clean' driving record (no at fault accidents in past 10 years, see the footnote that follows this sentence) and a 'poor' record defined as one partially at-fault accident and one speeding ticket over the past three years. ${ }^{2}$ For the private insurance regimes, the Kanetix web site provides a host of prices for the identified driver from several companies (but the company with the 'lowest' price in Ontario is not identified, one has to contact Kanetix directly for this information). ${ }^{3}$ In addition, price quotes were obtained from several other large insurance companies either by telephone or on line. All prices were obtained in May-June 2017.

All price quotes were obtained for the 'mandated' coverage (as required by law, and defined in tables $\mathrm{A} 1 \mathrm{a}$ and $\mathrm{A} 1 \mathrm{~b}$ ) and for a 'complete' package with higher-than-mandated liability limits, comprehensive 
coverage, as well as other benefits (defined in Appendix table A3). One important caveat is that in the private regimes, insurance companies typically do not offer packages with just the minimum prescribed third party insurance amounts, as these are inadequate to cover damages in the event of an accident. Normally, insurance companies require that one takes out at least one million dollars in such coverage (whereas the mandated amount is $\$ 200,000$ in most jurisdictions). In the public regime, the minimum mandated amount is provided. Table A3 also provides the minimum amounts of liability coverage available by jurisdiction.

For the public regimes, the prices were obtained in Manitoba from the Autopac web site; in Saskatchewan, basic coverage was obtained from the SGI web site and the complete package was obtained by telephone from the broker companies located around the postal code of the representative driver, recommended on the SGI website ${ }^{4}$. All of the information for British Columbia was also obtained by calling the brokers recommended on the ICBC website around the postal code of the driver.

All of the data gathered on prices are provided in the Appendix, tables A4a-d. Tables A4a-d present all of the price quotes received by jurisdiction and important notes to take into account. Table A4a contains prices for the private provinces for our representative driver with a good driving record; table A4b contains the same for a poor driving record (except for Newfoundland and Labrador which did not provide quotes for poor drivers). Tables A4c and d present the same information but this time for the public provinces. Before turning to a discussion of pricing tendencies from tables A4a-d, it is interesting to note that for the 45-year-old driver featured here, the insurance price for women is often higher than that for men. It is for young drivers that the opposite occurs: young men are typically charged higher prices than young women in private regimes. For instance, a 21 years old female student living at home but principal driver of the aforementioned 2008 Honda Civic, is charged at least $\$ 3,459$ for the mandated coverage, whereas an otherwise similar male would be charged $\$ 3,997.5$

In order to focus the discussion, the key data from tables A4a-d are synthesized and presented in table 1. Table 1 reports three prices (with a fourth for Ontario) each for males and for females, for mandated coverage and for complete (optional) coverage, and for a clean driving record and for a poor driving record (as previously defined). The three prices are as follows: the first number is the minimum price quoted by an identified insurance company; the next number below is the 
TABLE 1 Price Quotes for 45 year old, Employed Driver (Honda Civic) Source: Appendix Tables A4a-d

\begin{tabular}{|c|c|c|c|c|c|c|c|c|}
\hline & \multicolumn{4}{|c|}{ CLEAN RECORD } & \multicolumn{4}{|c|}{ POOR RECORD } \\
\hline & \multicolumn{2}{|c|}{$\begin{array}{l}\text { Required } \\
\text { Coverage }\end{array}$} & \multicolumn{2}{|c|}{$\begin{array}{l}\text { Complete } \\
\text { Coverage }\end{array}$} & \multicolumn{2}{|c|}{$\begin{array}{l}\text { Required } \\
\text { Coverage }\end{array}$} & \multicolumn{2}{|c|}{$\begin{array}{l}\text { Complete } \\
\text { Coverage }\end{array}$} \\
\hline & Female & Male & Female & Male & Female & Male & Female & Male \\
\hline Ontario (Toronto) & 1,671 & 1,661 & 1,815 & 1,930 & 2,538 & 2,493 & 3,149 & 3,255 \\
\hline Maximum & 3,948 & 3,948 & 4,724 & 4,463 & 6,572 & 6,572 & 7,809 & 7,809 \\
\hline Unspecified Minimum & $\mathrm{N} / \mathrm{A}$ & 1,285 & $\mathrm{~N} / \mathrm{A}$ & 1,727 & $\mathrm{~N} / \mathrm{A}$ & $\mathrm{N} / \mathrm{A}$ & $\mathrm{N} / \mathrm{A}$ & $\mathrm{N} / \mathrm{A}$ \\
\hline Average & 2,464 & 2,497 & 2,815 & 2,848 & 4,394 & 4,354 & 5,295 & 5,259 \\
\hline Alberta (Calgary) & 669 & 667 & 1,223 & 1,223 & 1,216 & 1,216 & 2,481 & 2,481 \\
\hline Maximum & 978 & 902 & 1,897 & 1,954 & 1,236 & 1,236 & 2,862 & 2,991 \\
\hline Average & 796 & 782 & 1,466 & 1,473 & 1,223 & 1,223 & 2,663 & 2,669 \\
\hline Nova Scotia (Halifax) & 653 & 643 & 1,032 & 1,032 & 856 & 845 & 1,464 & 1,479 \\
\hline Maximum & 924 & 924 & 1,433 & 1,190 & 1,374 & 1,374 & 2,153 & 2,153 \\
\hline Average & 764 & 760 & 1,170 & 1,176 & 1,115 & 1,110 & 1,809 & 1,816 \\
\hline PEI (Charlottetown) & 391 & 391 & 1,002 & 1,002 & 554 & 554 & 1,545 & 1,604 \\
\hline Maximum & 629 & 629 & 1,213 & 1,213 & 887 & 887 & 1,967 & 1,967 \\
\hline Average & 517 & 516 & 1,074 & 1,085 & 721 & 721 & 1,756 & 1,756 \\
\hline NB (Moncton) & 587 & 587 & 1,049 & 1,049 & 933 & 933 & 1,432 & 1,432 \\
\hline Maximum & 898 & 898 & 1,349 & 1,349 & 2,035 & 2,035 & 2,776 & 2,776 \\
\hline Average & 775 & 775 & 1,180 & 1,180 & 1,484 & 1,481 & 2,102 & 2,104 \\
\hline NL (St Johns) & 918 & 918 & 1,329 & 1,329 & & & & \\
\hline Maximum & 1,751 & 1,751 & 2,377 & 2,377 & & & & \\
\hline Average & 1,258 & 1,258 & 1,832 & 1,832 & & & & \\
\hline BC (Vancouver) & 1,064 & 1,064 & 1,618 & 1,618 & 1,514 & 1,514 & 1,743 & 1,743 \\
\hline Maximum & 1,123 & 1,123 & 2,372 & 2,372 & 1,618 & 1,618 & 2,640 & 2,640 \\
\hline Average & 1,087 & 1,087 & 1,853 & 1,853 & 1,571 & 1,571 & 2,310 & 2,310 \\
\hline Manitoba (Winnipeg) & 1,167 & 1,167 & 1,451 & 1,451 & 1,239 & 1,239 & 1,541 & 1,541 \\
\hline Maximum & 1,167 & 1,167 & 1,451 & 1,451 & 1,239 & 1,239 & 1,541 & 1,541 \\
\hline Average & 1,167 & 1,167 & 1,451 & 1,451 & 1,239 & 1,239 & 1,541 & 1,541 \\
\hline Saskatchewan (Saskatoon) & 917 & 917 & 1,125 & 1,125 & 978 & 978 & 1,186 & 1,186 \\
\hline Maximum & 917 & 917 & 1,142 & 1,142 & 978 & 978 & 1,196 & 1,196 \\
\hline Average & 917 & 917 & 1,131 & 1,131 & 978 & 978 & 1,192 & 1,192 \\
\hline
\end{tabular}


maximum price quoted by an identified insurance company; underneath the maximum price in Ontario only is the 'lowest unspecified price' from Kanetix; ${ }^{6}$ lastly, I report the average of all of the quotes obtained. All of this information is given for all provinces except Quebec: the private regimes are presented first followed by the public ones.

\section{a) Private Insurance Regime Prices}

Several observations can be made from Table 1 with respect to the private provinces. First, it reveals the importance of driving record-for mandatory coverage, a poor record for a driver in Toronto, Ontario, results in an increase in the lowest rates from $\$ 1,406$ to $\$ 2,538$ for a woman, and from $\$ 1,661$ to $\$ 2,493$ for a man. In Calgary, Alberta, the comparable minimum coverage rates go from $\$ 669$ to $\$ 1,216$ for females and from $\$ 667$ to $\$ 1,216$ for males. Table 1 also reveals the importance of coverage-moving from the mandated coverage to a more complete coverage results in a significant increase in rates. For the 45-year-old male living in Toronto, his best price goes from $\$ 1,661$ (mandatory package) to $\$ 1,930$ (complete package). The prices in the Maritime Provinces are different than in Ontario, but display a similar pattern.

Whereas the previous paragraph focused on the lowest price quoted for the private regimes, if one looks at the average of all of the quoted prices (as reported in Tables A4a and b), it renders even clearer that Ontario is by far the most expensive province for drivers, irrespective of sex or driving record. It is actually quite startling the magnitude of the rates quoted for Toronto relative to these other, albeit much smaller, cities.

Finally, with respect to the private regimes, there is a huge difference between the prices quoted for Ontario (Toronto) and for the other provinces especially for the basic, mandated, coverage. These differences are smaller when one compares prices for the complete insurance package, but it is clear that population size (actually, more likely to be population density) plays a role in explaining prices.

\section{b) Public Insurance Regime Prices}

Information on prices from the three public jurisdictions (excluding Quebec) is presented in the bottom part of table 1. These prices do not vary by gender but do vary by driving record. All prices reported 
for the public provinces exclude registration and licensing fees which were initially reported in the insurance price: $\$ 161$ were subtracted in Manitoba, \$68 in Saskatchewan and \$61 in BC.

The price for someone with a clean driving record and mandatory coverage in Winnipeg, Manitoba is $\$ 1,167$ and for the extended, 'complete' coverage, it is $\$ 1,451$. In Saskatoon, Saskatchewan, basic coverage costs $\$ 917$ while the price of complete coverage varies a bit according to brokers used, from $\$ 1,125$ to $\$ 1,217$. In Vancouver, British Columbia, both basic coverage and the optional (complete) plan vary by broker: from $\$ 1,064$ to $\$ 1,123$ (basic) and from $\$ 1,618$ to $\$ 2,372$ (complete).

Only in $\mathrm{BC}$ is there some variation in the prices quoted across the coverages. But the variation is quite small when compared to what was observed in the private jurisdictions. As a consequence, average prices are only slightly different than the minimum price indicated for BC in table 1 .

Having a poor driving record also leads to an increase in the price of insurance in the public provinces. Basic coverage goes up from $\$ 1,167$ to $\$ 1,239$ in Manitoba, from $\$ 917$ to $\$ 978$ in Saskatchewan, and the minimum quote in $\mathrm{BC}$ moves from $\$ 1,064$ to $\$ 1,514$. Even though the population of Greater Vancouver, at 2.46 million, is the same as the population of the other two public provinces combined (Saskatchewan with 1.15 million and Manitoba with 1.32 million) and far exceeds the population in the other two cities, the amount charged a driver in Vancouver for required coverage is less than that of Winnipeg ( $\$ 1,064$ versus $\$ 1,167)$, and not far off of the lowest-priced jurisdiction, Saskatoon (\$917). ${ }^{7}$ Once complete coverage is taken into account, the Vancouver driver pays a bit more $(\$ 1,618$ versus $\$ 1,451)$, but still surprisingly close given the huge population differences in these jurisdictions.

The average prices of the minimum required insurance package across the three public auto insurance provinces are remarkably similar. Saskatchewan charges the lowest price on average, Manitoba charges the highest on average, and BC is in the middle. Once again, the fact that Vancouver is significantly larger and more densely populated than either Saskatoon or Winnipeg would lead one to anticipate significantly higher prices in Vancouver, but this is not clearly revealed by the data. Moreover, the fact that Saskatchewan and Manitoba run no-fault systems with restrictions on the right to sue for pain and suffering might 
also lead to the expectation of clearly lower prices in these jurisdictions relative to the liability-based province of British Columbia-but this is not the case either.

\section{c) Comparing BC Prices to other Public and Private Insurance Regimes}

With much caution, one can compare across private and public regimes. To facilitate this comparison, table 2 extracts the average prices from table 1 for the minimum required insurance package for each province for the 45-year-old employed female or male driver of a Honda Civic, with a clean driving record. These average prices are reported from highest to lowest.

TABLE 2 Average Price for Minimum Required Coverage: 45 year old, Employed Driver (Honda Civic) Extracted from Table 1

\begin{tabular}{l|c|c}
\multicolumn{1}{l|}{ PROVINCE } & FEMALE & MALE \\
Ontario (Toronto) & 2,464 & 2,497 \\
\hdashline Newfoundland (St. John's) & 1,258 & 1,258 \\
\hline Manitoba (Winnipeg) & 1,167 & 1,167 \\
\hdashline British Columbia (Vancouver) & 1,087 & 1,087 \\
\hline Saskatchewan (Saskatoon) & 917 & 917 \\
\hline Alberta (Calgary) & 796 & 782 \\
\hline New Brunswick (Moncton) & 775 & 775 \\
\hline Nova Scotia (Halifax) & 764 & 760 \\
\hline PE (Charlottetown) & 517 & 516 \\
\hline
\end{tabular}

From table 2 it is clear that the average price in British Columbia (Vancouver) is in the middle of the pack and most closely comparable to the prices in Manitoba and Saskatchewan, the other two public jurisdictions. The two largest cities in this sample are Vancouver and Toronto: the Greater Toronto Area has a population of 6.42 million, while Greater Vancouver has 2.46 million. However, a driver with a good record in Vancouver pays significantly less (in fact less than half for the driver featured in table 2) than an otherwise comparable driver in Toronto. This observation is particularly interesting because Toronto is in a no-fault province that has already severely restricted the right 
to sue for pain and suffering for all but severe injuries which was theoretically supposed to keep costs (and hence prices) down, whereas Vancouver is in a liability-based regime.

Once again, it is important to remember that the insurance packages are not entirely comparable across jurisdictions. The focus on mandatory packages, and minimum quotes, helps to determine the cost of entry into driving by province-which is somewhat comparable across jurisdictions. But from tables $1 \mathrm{~A}$ and $\mathrm{B}$, one can see that there are differences across many of the benefits provided in the mandatory packages, affecting prices.

\section{Comparing Costs across Public and PRIVATE Regimes}

Before turning to comparisons of insurance costs, it is necessary to understand a couple of fundamental differences between public and private regimes when it comes to collecting and interpreting data. Since 2011, data for the private provinces are available from the General Insurance Statistical Agency (GISA) “... an independent legal entity under the Canada Corporations Act ... to carry out the activities of a statistical agent on behalf of all participating Canadian jurisdictions." The Insurance Bureau of Canada collects this data on behalf of GISA. Efforts are made to render these data as accurate as possible, hence facilitating interprovincial comparisons. No comparable information prior to 2011 was available from IBC.

Some information is not included in the available GISA data, most importantly from the point of view of this comparison, is the exemption of Facility Association residual market information. High-risk drivers, who cannot obtain automobile insurance through conventional means, have to apply to a Facility Association, which provides them with coverage typically by facilitating a risk-pooling contract across several companies. Facility Associations exist in all privately provided automobile insurance regimes because automobile insurance is mandatory. Not only is the information from these high risk drivers exempt from GISA data, but so too is information from uninsured drivers. ${ }^{9}$ The Facility Associations have an uninsured motorist fund that indemnifies victims of uninsured drivers. Thus, GISA data does not include all of the very high risk portion of the driving population. 
By contrast, data from public insurance provinces are obtained from the public insurer itself. These data include all drivers, even the high risk ones. And each public insurer has a fund to deal with uninsured drivers. In other words, the insurance data presented below include all insured drivers in the public jurisdictions but not in the private jurisdictions were data on the riskiest group is excluded.

In addition to these exclusions, there is potentially a fundamental difference between the number of claims reported in a liability-based private system versus a first-party-based public one. In a liability regime, a driver involved in an accident through no fault of his/her own, will not typically make a claim on his/her own insurance policy. The claim will be on the at-fault driver's policy. As a result, such an accident with two vehicles, say, will result in one claim. In the public, first-party, system, such an accident would yield two claims, one for each vehicle. We cannot, then, compare number of claims across these two systems, which is apparent in the next section.

\section{a) Interprovincial Comparisons: Loss Ratios and Average Claim Costs}

Notwithstanding the difficulties associated with comparing insurance regimes across provinces, a simple measure of the costs of insurance provision is looked at: the "Claim and Adjustment Expenses Incurred" divided by the "Earned Premiums"-known as the "Earned Incurred Loss Ratio" (referred to as the "Loss Ratio"). The claim and adjustment expenses refer to the amounts reported by insurance companies directly associated with claims. Earned premiums are the premiums paid for the policies during the fiscal year: if someone began their policy half way through the year but paid for a full year in advance, only one-half of these premiums would count in this number. Similarly, if someone were to cancel their policy during the year, the amount reimbursed would be netted out of this figure.

The focus on the loss ratio allows one to find reasonably comparable information for all jurisdictions (except Quebec). The loss ratio provides a measure of the amount of money paid out for claims relative to the amount of premiums earned: the larger this number, the closer premiums reflect claims. As this ratio approaches one, claim costs approach premiums paid and arguably this implies that there is less 'waste' in the system. As a result, the loss ratio has been treated as a 
measure of performance. But it is an imperfect one. This ratio can be high for several reasons, including premiums being set 'too low'; claims being 'too high'; or a combination of both of these factors.

That being said, the loss ratio is one way to compare jurisdictions. Like before, it makes sense to continue to discuss the private and public systems separately. The top half of table 3 presents the earned premiums and claim expenses for the private systems: the four Atlantic Provinces (together), Ontario and Alberta, for the five-year period: 2011 to 2015. As previously indicated, all of these data are gathered from the same source, the General Insurance Statistical Agency, which helps render them comparable. The second half of the table reports the public regimes.

TABLE 3 Earned Premiums, Claim and Adjustment Expenses Incurred and Earned Incurred Loss Ratio

\begin{tabular}{|c|c|c|c|c|}
\hline PROVINCE & $\begin{array}{l}\text { COVERAGE AND } \\
\text { ACCIDENT YEAR }\end{array}$ & EARNED PREMIUMS & $\begin{array}{c}\text { CLAIM AND } \\
\text { ADJUSTMENT } \\
\text { EXPENSES INCURRED }\end{array}$ & $\begin{array}{l}\text { EARNED } \\
\text { INCURRED LOSS } \\
\text { RATIO (\%) }\end{array}$ \\
\hline \multirow[t]{6}{*}{ Alberta } & 2011 & $2,476,498,770$ & $1,737,461,860$ & 70 \\
\hline & 2012 & $2,583,782,815$ & $2,023,238,074$ & 78 \\
\hline & 2013 & $2,738,168,536$ & $2,156,806,256$ & 79 \\
\hline & 2014 & $2,931,948,823$ & $2,357,661,553$ & 80 \\
\hline & 2015 & $3,093,938,231$ & $2,491,948,366$ & 81 \\
\hline & Total & $13,824,337,175$ & $10,767,116,109$ & 78 \\
\hline \multirow[t]{6}{*}{ Atlantic Provinces } & 2011 & $1,163,948,471$ & $777,985,471$ & 67 \\
\hline & 2012 & $1,174,441,574$ & $804,537,082$ & 69 \\
\hline & 2013 & $1,184,283,171$ & $865,660,975$ & 73 \\
\hline & 2014 & $1,199,866,294$ & $901,404,977$ & 75 \\
\hline & 2015 & $1,218,228,911$ & $981,135,267$ & 81 \\
\hline & Total & $5,940,768,422$ & $4,330,723,772$ & 73 \\
\hline \multirow[t]{6}{*}{ Ontario } & 2011 & $10,037,791,312$ & $6,322,237,101$ & 63 \\
\hline & 2012 & $10,439,481,575$ & $6,274,427,278$ & 60 \\
\hline & 2013 & $10,582,013,779$ & $6,806,718,445$ & 64 \\
\hline & 2014 & $10,538,886,511$ & $7,103,631,213$ & 67 \\
\hline & 2015 & $10,378,560,055$ & $7,600,789,200$ & 73 \\
\hline & Total & $51,976,733,233$ & $34,107,803,237$ & 66 \\
\hline
\end{tabular}




\begin{tabular}{|c|c|c|c|c|}
\hline PROVINCE & $\begin{array}{l}\text { COVERAGE AND } \\
\text { ACCIDENT YEAR }\end{array}$ & EARNED PREMIUMS & $\begin{array}{c}\text { CLAIM AND } \\
\text { ADJUSTMENT } \\
\text { EXPENSES INCURRED }\end{array}$ & $\begin{array}{l}\text { EARNED } \\
\text { INCURRED LOSS } \\
\text { RATIO (\%) }\end{array}$ \\
\hline \multirow[t]{11}{*}{ British Columbia } & 2006 & $3,256,856,000$ & $2,944,453,000$ & 90 \\
\hline & 2007 & $3,482,434,000$ & $2,914,550,000$ & 84 \\
\hline & 2008 & $3,631,215,000$ & $2,819,138,000$ & 78 \\
\hline & 2009 & $3,650,025,000$ & $2,970,125,000$ & 81 \\
\hline & 2010 & $3,667,324,000$ & $3,074,228,000$ & 84 \\
\hline & 2011 & $3,673,210,000$ & $3,186,563,000$ & 87 \\
\hline & 2012 & $3,811,386,000$ & $3,276,291,000$ & 86 \\
\hline & 2013 & $3,927,694,000$ & $3,434,660,000$ & 87 \\
\hline & 2014 & $4,158,695,000$ & $3,894,833,000$ & 94 \\
\hline & 2015 & $4,447,931,000$ & $4,363,495,000$ & 98 \\
\hline & Total & $37,706,770,000$ & $32,878,336,000$ & 86 \\
\hline \multirow[t]{11}{*}{ Saskatchewan* } & 2006 & $542,204,000$ & $449,072,000$ & 83 \\
\hline & 2007 & $557,087,000$ & $532,217,000$ & 96 \\
\hline & 2008 & $587,918,000$ & $563,965,000$ & 96 \\
\hline & 2009 & $630,559,000$ & $600,432,000$ & 95 \\
\hline & 2010 & $684,821,000$ & $609,673,000$ & 89 \\
\hline & 2011 & $726,282,000$ & $806,924,000$ & 111 \\
\hline & 2012 & $767,226,000$ & $740,528,000$ & 97 \\
\hline & 2013 & $806,965,000$ & $739,103,000$ & 92 \\
\hline & 2014 & $863,976,000$ & $834,155,000$ & 97 \\
\hline & 2015 & $925,678,000$ & $753,031,000$ & 82 \\
\hline & Total & $7,092,716,000$ & $6,629,100,000$ & 93 \\
\hline \multirow[t]{11}{*}{ Manitoba* } & 2006 & $798,811,000$ & $731,689,000$ & 92 \\
\hline & 2007 & $828,121,000$ & $728,675,000$ & 88 \\
\hline & 2008 & $865,056,000$ & $723,430,000$ & 84 \\
\hline & 2009 & $895,811,000$ & $736,514,000$ & 82 \\
\hline & 2010 & $918,905,000$ & $547,320,000$ & 60 \\
\hline & 2011 & $935,385,000$ & $850,003,000$ & 91 \\
\hline & 2012 & $940,910,000$ & $889,211,000$ & 95 \\
\hline & 2013 & $956,350,000$ & $1,009,260,000$ & 106 \\
\hline & 2014 & $1,001,770,000$ & $992,897,000$ & 99 \\
\hline & 2015 & $1,070,182,000$ & $920,452,000$ & 86 \\
\hline & Total & $9,211,301,000$ & $8,129,451,000$ & 88 \\
\hline
\end{tabular}

Sources: See Table A5 in the Appendix.

\section{Notes}

* The Saskatchewan Auto Fund transitioned to a March 31 year end in 2015. The current fiscal period represents the 15 months ended March 31, 2016.

${ }^{* *}$ Manitoba's Annual Reports results are based on a Fiscal year ending February 28/29. 
Starting first with the private systems, three points are worthy of note from table 3. First, the loss ratio in Alberta is the highest in every year but the last one where it is the same as in the Atlantic Provinces. Second, Ontario always has the lowest loss ratio of this group. Finally, except for in 2012 in Ontario, the loss ratios increase every year in every jurisdiction. If one interprets this ratio as being a measure of good performance, table 3 suggests that Alberta performs better than the other jurisdictions (although it is tied with the Atlantic Provinces in 2015), and Ontario is the worst. Again, caution is required here, for the reasons stated earlier. The fact that these ratios are rising can be interpreted as meaning that the industry is performing better. But ... it may also be an indicator of impending financial difficulty to the extent that claims being paid out are approaching premiums earned.

On the topic of financial difficulty, a main source of revenue in the insurance market is returns to investments. The nature of the insurance market is such that firms collect a massive amount of money regularly, but have much more irregular payouts. Investment income is an important revenue component. Table 4 presents the average returns on equity and investment, as well as loss ratios across the country (private property and casualty insurance, of which automobile insurance is the largest component) according to the Insurance Bureau of Canada (Fact Book, 2017, p.14). ${ }^{10}$ The main point to notice from this table is the falling rate of return on investments over the 2011 to 2015 period. This falling rate adversely affects the size of the revenues generated for insurance companies. As these revenues fall, shortfalls have to be made up elsewhere-principally through premium hikes or claim reductions. All insurance regimes are in the same boat when it comes to the problem of investment income. Although, arguably, public regimes have recourse to other sources of revenue (discussed briefly below).

Returning to table 3, the bottom half presents the Earned Incurred Loss Ratio for the three public provinces included in this report. Before analyzing these data, a few remarks are necessary. In 2015, the Saskatchewan Auto Fund moved to a March 31st year end and hence the data for 2015 actually comprise 15 months; the financial year is ended February 28th (29th) in Manitoba; and in 2015 the Insurance Corporation of British Columbia announced that it was no longer considering the Loss Ratio as a performance measure effective with the 2015-2017 Service Plan (this was calculated by the author and provided in table 3). ${ }^{11}$ 
TABLE 4 Canada Wide Returns on Investment and Equity for the Property -Causality Insurance

\begin{tabular}{|c|c|c|c|c|c|}
\hline & $\begin{array}{l}\text { RETURN } \\
\text { EQUITY* }\end{array}$ & $\begin{array}{l}\text { RETURN } \\
\text { INVESTMENT }\end{array}$ & $\begin{array}{l}\text { EARNED LOSS } \\
\text { RATIO }\end{array}$ & $\begin{array}{c}\text { OPEERATING } \\
\text { EXPENSE RATIO }\end{array}$ & $\begin{array}{l}\text { COMBINED } \\
\text { RATIO }\end{array}$ \\
\hline 1993 & $9.5 \%$ & $10.7 \%$ & $77.1 \%$ & $32.8 \%$ & $109.9 \%$ \\
\hline 1994 & $6.8 \%$ & $8.0 \%$ & $75.7 \%$ & $31.3 \%$ & $107.0 \%$ \\
\hline 1995 & $11.7 \%$ & $9.1 \%$ & $73.3 \%$ & $30.8 \%$ & $104.1 \%$ \\
\hline 1996 & $13.6 \%$ & $10.3 \%$ & $72.7 \%$ & $30.7 \%$ & $103.4 \%$ \\
\hline 1997 & $13.1 \%$ & $10.4 \%$ & $71.4 \%$ & $31.2 \%$ & $102.6 \%$ \\
\hline 1998 & $6.8 \%$ & $8.5 \%$ & $74.9 \%$ & $32.9 \%$ & $107.8 \%$ \\
\hline 1999 & $6.5 \%$ & $7.3 \%$ & $72.6 \%$ & $33.2 \%$ & $105.9 \%$ \\
\hline 2000 & $6.3 \%$ & $9.0 \%$ & $75.9 \%$ & $32.7 \%$ & $108.7 \%$ \\
\hline 2001 & $2.6 \%$ & $7.5 \%$ & $80.0 \%$ & $31.0 \%$ & $111.0 \%$ \\
\hline 2002 & $1.7 \%$ & $5.4 \%$ & $76.9 \%$ & $28.9 \%$ & $105.8 \%$ \\
\hline 2003 & $11.6 \%$ & $6.2 \%$ & $69.9 \%$ & $28.6 \%$ & $98.4 \%$ \\
\hline 2004 & $18.1 \%$ & $5.6 \%$ & $62.7 \%$ & $28.2 \%$ & $91.0 \%$ \\
\hline 2005 & $17.2 \%$ & $5.9 \%$ & $64.7 \%$ & $28.7 \%$ & $93.4 \%$ \\
\hline 2006 & $16.9 \%$ & $5.9 \%$ & $59.5 \%$ & $28.1 \%$ & $87.5 \%$ \\
\hline 2007 & $14.1 \%$ & $5.5 \%$ & $62.5 \%$ & $28.5 \%$ & $91.0 \%$ \\
\hline 2008 & $6.0 \%$ & $3.9 \%$ & $70.3 \%$ & $30.0 \%$ & $100.3 \%$ \\
\hline 2009 & $6.9 \%$ & $4.2 \%$ & $69.5 \%$ & $30.0 \%$ & $99.6 \%$ \\
\hline 2010 & $7.6 \%$ & $4.3 \%$ & $69.1 \%$ & $30.2 \%$ & $99.4 \%$ \\
\hline 2011 & $8.0 \%$ & $4.2 \%$ & $68.2 \%$ & $30.3 \%$ & $98.4 \%$ \\
\hline 2012 & $10.8 \%$ & $3.9 \%$ & $64.7 \%$ & $30.6 \%$ & $95.3 \%$ \\
\hline 2013 & $6.9 \%$ & $3.1 \%$ & $68.1 \%$ & $30.8 \%$ & $98.9 \%$ \\
\hline 2014 & $9.9 \%$ & $3.9 \%$ & $66.6 \%$ & $31.0 \%$ & $97.6 \%$ \\
\hline 2015 & $10.0 \%$ & $3.3 \%$ & $63.5 \%$ & $31.4 \%$ & $94.9 \%$ \\
\hline 2016 & $6.0 \%$ & ${ }^{* \star} 2.7 \%$ & $67.6 \%$ & $31.8 \%$ & $99.4 \%$ \\
\hline
\end{tabular}

* Excluding Lloyd's

${ }^{* *}$ As per the latest OSFI regulatory filing forms, which came into effect Q4 2016

Source: Copied directly from: IBC (2017) Facts Book, p. 14, accessed at: http://assets.ibc.ca/Documents/Facts\%20Book/Facts_ Book/2017/Fact-Book-2017.pdf 
Looking across the three public jurisdictions, one finds quite a bit of variation in the loss ratio over time. For the first five years of the data (2006-2010), this ratio basically falls in BC, rises then falls in Saskatchewan, but not to as low a level as it began in 2006, and falls in Manitoba (although the rate of 60 in 2010 seems anomalously low). For the second part of the data series, namely from 2011 to 2015, the period for which private insurance regime data are also available, different patterns are displayed. It basically rises in BC, falls (but not continuously) in Saskatchewan, where it began from an anomalously high level of 111, and rises then falls in Manitoba. Over this latter fiveyear period, the loss ratio in $\mathrm{BC}$ is the lowest when compared to Saskatchewan and Manitoba, except in 2015 when it is the highest. It is also notable that twice the loss ratio is greater than one-meaning that claims exceeded earned premiums in that period. Overall, therefore, when comparing the loss ratios of the three public auto insurance provinces of BC, Saskatchewan and Manitoba, it is clear that they fluctuate significantly from year to year and that no one single province has performed consistently or significantly better than the others. $\mathrm{BC}$ has remained in the pack.

Altogether there is a remarkable amount of year-to-year variation in this loss ratio in both the private and public jurisdictions. This observation suggests that much caution needs to be taken when relying on this figure in any given year. It is likely to be meaningful to make a statement about a continuously rising or continuously falling loss ratio-such a pattern would be suggestive, but when it regularly goes up and down, as is observed in table 3, it is difficult to rely on it as an indicator of performance one way or another. Table 3 provides the total loss ratio over the period of the data series-one can see quite clearly that this total loss ratio bears very little resemblance to, say, the loss ratio of 2015. In $\mathrm{BC}$, for instance, it happens to have the highest loss ratio in 2015 at 98 across all of the jurisdictions, but, at 86 , it has the lowest total loss ratio across the three public provinces for the ten years of the data set, followed closely by Manitoba with 88. Ontario, with 66, has the lowest total loss ratio of all reported jurisdictions.

Comparing across the private and public jurisdictions reveals that the loss ratio is almost always highest in the public regimes (except for 2010 in Manitoba). One interpretation of this observation is that the public regimes are outperforming the private ones insofar as their claims are closer to earned premiums-but this is too facile an interpretation for the reasons already stated. Moreover, because public regimes may have more ready access to other sources of revenue typically not available to private companies, including fees for a variety 
of other, related, services, like drivers' permits and vehicle registrations, not to mention the possibility of transfers from general government revenues, this means that they can operate with a higher loss ratio relative to the private regimes. Another reason why public regimes may have a higher loss ratio is that their data include all of the high-risk drivers-those who would have to resort to a Facility Association in the private regimes, plus those who drive uninsured.

One might be tempted to compare the average cost of claims by province. However, as discussed above, public and private regimes are inherently different in the way in which claims are counted and hence comparisons across these regimes are inappropriate. Within regime comparisons can be made. To this end, information on claim and adjustment expenses previously reported in table 3 can be used, but now these amounts need to be expressed as 'real' dollars to take account of annual inflation. If one does not account for inflation, then rising claim costs may simply be reflecting general price increases rather than other factors. Inflation is taken into account by using the provincial consumer price indices each year. ${ }^{12}$ The year 2011 was chosen as the base (or reference) year, which means that all of the claim and adjustment expenses are expressed in 2011 dollars. Therefore, in table 3 the reported figures for 2011 are identical to those in table 5; for years prior to 2011, real claim expenses reported in table 5 are higher than those in table 3, and for years after 2011 they will look lower in table 5 compared to table 3 as the numbers are expressed in 2011 dollars. Once the 'real claim costs' (claim costs and adjustment expenses from table 3 divided through by the CPI) are obtained, this number can be divided by the number of claims each year to obtain the real average cost per claim. Table 5 provides the information on real claim costs in the column entitled "Real Claim and Adjustment Expenses Incurred"; and provides the information on the "Real Average Cost per Claim" in the last column. Remember, that the information in this last column cannot be compared across public and private regimes because of the way in which claims are calculated. Looking first at the three private regions (Alberta, Ontario and Atlantic Provinces), the (real) average cost of claims in Ontario is much higher than in the other two jurisdictions; the Atlantic Provinces are clearly the lowest on this measure. Reliable information for Saskatchewan could not be obtained; hence only two public regimes are reported in table 3. BC has higher average claim costs when compared to Manitoba. 
TABLE 5 Number of Earned Vehicles, Number of Claims, Real Claim and Adjustment Expenses Incurred and Real Average Cost per Claim

\begin{tabular}{|c|c|c|c|c|c|}
\hline PROVINCE & $\begin{array}{l}\text { COVERAGE AND } \\
\text { ACCIDENT YEAR }\end{array}$ & $\begin{array}{l}\text { NUMBER } \\
\text { OF EARNED } \\
\text { VEHICLES* }\end{array}$ & $\begin{array}{l}\text { NUMBER OF } \\
\text { CLAIMS }\end{array}$ & $\begin{array}{l}\text { REAL CLAIM AND } \\
\text { ADJUSTMENT } \\
\text { EXPENSES } \\
\text { INCURRED }\end{array}$ & $\begin{array}{c}\text { REAL } \\
\text { AVERAGE COST } \\
\text { PER CLAIM }\end{array}$ \\
\hline \multirow[t]{6}{*}{ Alberta } & 2011 & $2,307,347$ & 246,758 & $1,737,461,860$ & 7,041 \\
\hline & 2012 & $2,396,990$ & 271,795 & $2,000,952,210$ & 7,362 \\
\hline & 2013 & $2,490,256$ & 271,306 & $2,103,262,579$ & 7,752 \\
\hline & 2014 & $2,586,150$ & 280,845 & $2,241,740,221$ & 7,982 \\
\hline & 2015 & $2,656,122$ & 272,353 & $2,342,841,508$ & 8,602 \\
\hline & Total & $12,436,866$ & $1,343,057$ & $10,426,258,378$ & 7,748 \\
\hline \multirow[t]{6}{*}{ Atlantic } & 2011 & $1,374,134$ & 160,54 & $777,985,471$ & 4,846 \\
\hline & 2012 & $1,401,563$ & 153,552 & $789,305,161$ & 5,140 \\
\hline & 2013 & $1,423,561$ & 157,95 & $837,298,374$ & 5,301 \\
\hline & 2014 & $1,440,100$ & 162,946 & $857,399,657$ & 5,262 \\
\hline & 2015 & $1,459,626$ & 172,949 & $931,600,368$ & 5,387 \\
\hline & Total & $7,098,984$ & 807,936 & $4,193,589,030$ & 5,187 \\
\hline \multirow[t]{6}{*}{ Ontario } & 2011 & $6,651,053$ & 610,535 & $6,322,237,101$ & 10,355 \\
\hline & 2012 & $6,766,018$ & 592,948 & $6,186,853,170$ & 10,434 \\
\hline & 2013 & $6,855,617$ & 620,882 & $6,646,234,839$ & 10,705 \\
\hline & 2014 & $6,953,621$ & 634,489 & $6,776,378,941$ & 10,680 \\
\hline & 2015 & $7,080,296$ & 657,761 & $7,165,265,172$ & 10,893 \\
\hline & Total & $34,306,604$ & $3,116,615$ & $33,096,969,223$ & 10,613 \\
\hline \multirow[t]{11}{*}{ British Columbia } & 2006 & $3,012,000$ & 947,000 & $3,173,254,158$ & 3,351 \\
\hline & 2007 & $3,108,000$ & 992,000 & $3,086,773,409$ & 3,112 \\
\hline & 2008 & $3,193,000$ & 964,000 & $2,924,573,259$ & 3,034 \\
\hline & 2009 & $3,225,000$ & 946,000 & $3,081,207,146$ & 3,257 \\
\hline & 2010 & $3,281,000$ & 895,000 & $3,147,166,626$ & 3,516 \\
\hline & 2011 & $3,321,000$ & 900,000 & $3,186,563,000$ & 3,541 \\
\hline & 2012 & $3,372,000$ & 915,000 & $3,240,134,987$ & 3,541 \\
\hline & 2013 & $3,429,000$ & 917,000 & $3,399,642,226$ & 3,707 \\
\hline & 2014 & $3,493,000$ & 900,000 & $3,816,215,681$ & 4,240 \\
\hline & 2015 & $3,596,000$ & 858,000 & $4,229,177,766$ & 4,929 \\
\hline & Total & $33,030,000$ & $9,234,000$ & $33,284,708,259$ & 3,623 \\
\hline
\end{tabular}




\begin{tabular}{|c|c|c|c|c|c|}
\hline PROVINCE & $\begin{array}{l}\text { COVERAGE AND } \\
\text { ACCIDENT YEAR }\end{array}$ & $\begin{array}{l}\text { NUMBER } \\
\text { OF EARNED } \\
\text { VEHICLES* }\end{array}$ & $\begin{array}{l}\text { NUMBER OF } \\
\text { CLAIMS }\end{array}$ & $\begin{array}{l}\text { REAL CLAIM AND } \\
\text { ADJUSTMENT } \\
\text { EXPENSES } \\
\text { INCURRED }\end{array}$ & $\begin{array}{c}\text { REAL } \\
\text { AVERAGE COST } \\
\text { PER CLAIM }\end{array}$ \\
\hline \multirow[t]{11}{*}{ Manitoba $^{\star *}$} & 2006 & & 269,135 & $796,982,315$ & 2,543 \\
\hline & 2007 & & 280,319 & $777,954,193$ & 2,355 \\
\hline & 2008 & & 254,856 & $755,327,266$ & 2,481 \\
\hline & 2009 & & 267,611 & $764,270,443$ & 2,381 \\
\hline & 2010 & & 275,763 & $563,501,635$ & 1,562 \\
\hline & 2011 & & 277,201 & $850,003,000$ & 2,532 \\
\hline & 2012 & & 287,105 & $875,166,936$ & 2,559 \\
\hline & 2013 & & 287,741 & $971,515,317$ & 2,881 \\
\hline & 2014 & & 273,244 & $938,220,310$ & 2,922 \\
\hline & 2015 & & 297,957 & $859,475,685$ & 2,667 \\
\hline & Total & & $2,770,932$ & $8,152,417,099$ & 2,488 \\
\hline
\end{tabular}

Sources

See Appendix, Table A5 and Statistics Canada, CANSIM Table 326-0021.

Notes

* Earned Vehicles refers essentially to the number of vehicles insured during the year, taking into account policies that start and end throughout the year. For instance, if an insurance policy began on July 1st, then it would be counted as a 0.5 of an earned vehicle during the calendar year.

** Manitoba has a fiscal year ending February 28 (29).

\section{OtheR FACTORS INFLUENCING the PRICE OF AUtOMOBILE INSURANCE}

Several factors influence the demand for automobile insurance, not the least of which is the number of vehicles on the road. Graph 1 presents the number of motor vehicle registrations per capita per province over the period 1999 to 2015 . A couple of broad points to note: the highest rate of per capita vehicle registrations is in Alberta, followed, occasionally very closely, by Saskatchewan. These two provinces are clearly higher than the others. The other regions are more clumped together, especially until about 2008 when we see Ontario having from then on the lowest per capita number of vehicles, and from 2009 the Atlantic Provinces trend upwards moving away from the pack. British Columbia has had a slight upward trend each year with a per capita rate of 0.57 in 1999 reaching a high of 0.66 in 2015 in par with the rate in Quebec and Manitoba. 


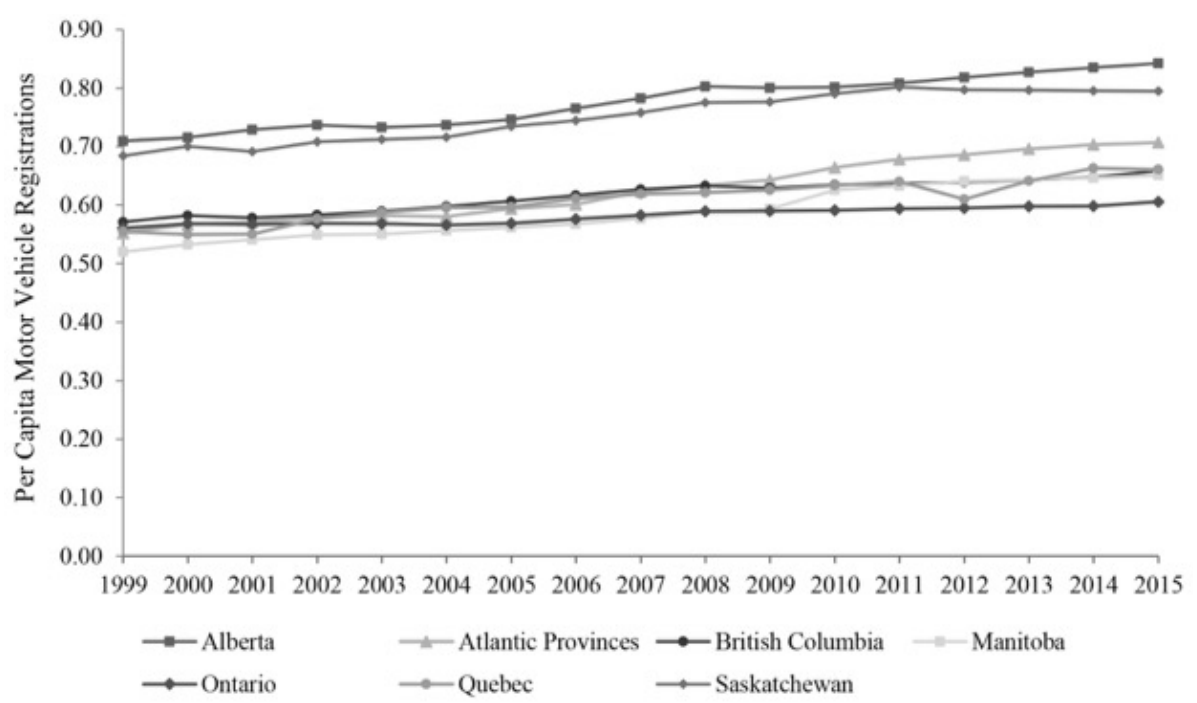

Sources: 1999 to 2015: Statistics Canada, CANSIM Table 405-0004 (Motor Vehicle Registrations); 1999 to 2015: Statistics Canada, CANSIM Table 051-0001 (population).

Another factor that influences the price of insurance is the number of accidents on the road. Typically, accidents are grouped into three main types: property-damage only, bodily- injuries, and fatal. The most comparable data on accidents are those gathered by police reports. One issue with these data, however, is the practice around when police are called to the scene. Small property-damage only accidents often are not attended by police, so these are the least comparable across jurisdictions. Problems exist with bodily-injury accidents as well insofar as police presence may not be required if the injuries are minor. The only type of accident that is accurately reported is fatal accidentsthese tend to provide a good indicator of driving risk over time. Graph 2 presents the rate of fatal accidents per 10,000 registered motor vehicles from 2002 to 2015 (excluding the Atlantic Provinces). Generally speaking, there is a downward trend in this rate: all of the rates are significantly lower in 2015 when compared to 2002. In 2002, the two jurisdictions with the highest fatality rates were Saskatchewan and British Columbia, with a rate of 1.7 fatal collisions per 10,000 registered vehicles (as opposed to, say, Ontario at 1.1). By 2015, the BC rate is clearly lower than that of Saskatchewan-0.9 versus 1.2 -and Saskatchewan continues to have the highest rate. Ontario has the lowest fatal collision rate across the board except for 2014 when Quebec held that distinction. 


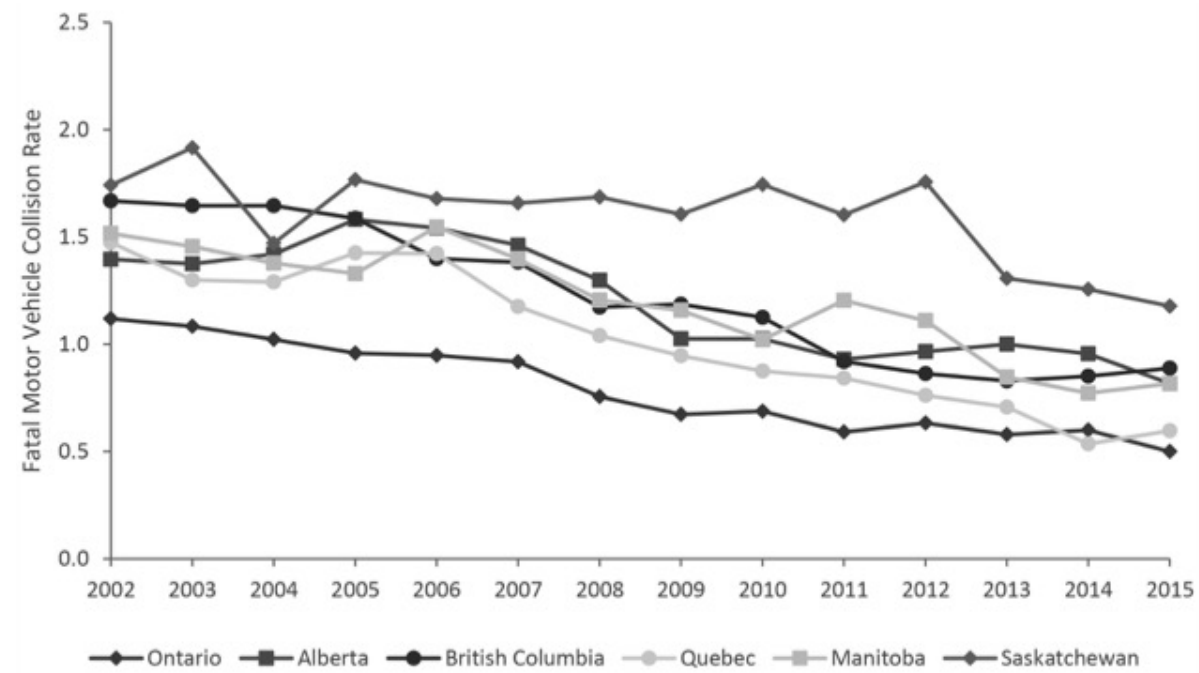

Sources

See table A5.

Notes

1. Ontario Statistics for 2015 and 2016 are preliminary statistics as of June 2017.

2. "Fatal Motor Vehicle collisions" include all reported motor vehicle crashes that resulted in at least one death, where death occurred within 30 days of the collision, except in Quebec before 2007 (eight days).

\section{A FeW Words ON PUBLIC VerSUS Private PROVISION OF INSURANCE}

The question as to whether automobile insurance is best provided by a public monopoly as opposed to by private insurers is one that has received little attention of late, but has been addressed in waves over the past decades. Currently, the public versus private debate rages on in the health care area, especially in the United States with its range of public, private and non- profit provision of medical services.

When it comes to the public versus private 'debate', much hinges on the impact of competition on prices and quality in comparison to potential cost savings associated with monopoly provision. In shortthe big question centres on whether or not the provision of (automobile) insurance is subject to large enough economies of scale to warrant a public monopoly. Very little empirical work has been done on this question for automobile insurance. Kennedy (1976) wrote a PhD thesis 
on this private versus public issue, and used as a case study the experience in Manitoba, with the introduction of its Autopac public insurance program in November, 1971, a couple of years before the ICBC creation in March, 1974. ${ }^{13}$ He compares this public provider with the private system in Alberta and concludes that neither had a clearly superior product (p.117) and that coordinating the licensing of drivers and vehicles with the provision of insurance led to fewer uninsured drivers on the road in Manitoba relative to Alberta, but that more product variety was available in the private system. He found that the price of basic coverage was cheaper in Alberta but for complete coverage, Manitoba was superior, although Autopac was allowed to run a deficit, which complicated this comparison.

\section{Concluding ReMARKS}

This article has used care and caution in presenting and analyzing data on automobile insurance regimes. By now, it should be clear that very few definite conclusions can be drawn. So what can be said? A particularly informative table is table 1 which provides a synthesis of the price quotes obtained by jurisdiction. From this table, two main conclusions can be drawn: prices charged in BC are in line with those of Manitoba (with some nuancing: for instance, BC tends to penalize poor driving records much more than either of the other public provinces). This holds true even though the demand for insurance in BC far exceeds that of the other two public provinces. A driver in Vancouver pays significantly less than an otherwise comparable driver in Toronto. The population in Toronto is larger which may justify some of this difference, but still the difference in some cases is quite remarkable.

One measure of performance is the earned incurred loss ratio which is reported in table 3; this paper has discussed why this ratio is not comparable across public and private regimes. In the private system, Ontario has the lowest loss ratios; in the public system, there is no discernable, stable, relationship across the three jurisdictions. BC is in the pack.

Average claim costs cannot be compared across regimes. In fact, one definite conclusion that can be made from this work is the extent to which differences in the way in which data are gathered in public versus private jurisdictions render comparisons across these two types of jurisdictions quite meaningless. 


\section{Road riskiness as measured by fatal accidents per 10,000 vehicles is falling over time. This is good news. Information on other types of accidents are not comparable either across jurisdictions or, indeed, across time within the same jurisdiction because of reporting rules.}

\section{NOTES}

1 This article was originally written for the Trial Lawyers Association (TLA) of BC to provide an interprovincial comparison of automobile insurance regimes in Canada. This project was undertaken on the strict understanding that data would be analyzed and conclusions would be reached from a neutral viewpoint, without any prior expectation one way or another. The TLA was agreeable to these terms.

2 From the Kanetix web site (see next footnote), these records are defined specifically as follows:

\section{Clean Record}

- At fault accidents in last 10 years: None

- Not at fault accidents in last 10 years: None

- Non-accident claims in last 6 years: None

- Tickets in last 3 years (not including parking tickets): None

Poor Record

- At fault accidents in last 10 years: One - Partially at fault accident

- Not at fault accidents in last 10 years: None

- Non-accident claims in last 6 years: None

- Tickets in last 3 years (not including parking tickets): One

- Speeding

3 The auto insurance price quotes were obtained from: https://www.kanetix.ca/auto-insurance. This web site harvests quotes from a long list of companies, found here: https://www.kanetix.ca/about_suppliers_gen.

4 Quebec is omitted partly because the insurance price includes driver license and registration fees and it was too difficult to render this price comparable to the others.

5 These were the minimum prices quoted from specified insurance companies from the Kanetix web site previously mentioned.

6 For Ontario, Kanetix provided an unidentified lowest price, but not for the other provinces.

7 All population data in this section are from the 2016 census, retrieved from CANSIM table number: 051-0001.

8 https://www.gisa.ca/

9 https://www.gisa.ca/Documents/View/2168 (p.6).

10 http://assets.ibc.ca/Documents/Facts\%20Book/Facts_Book/2017/Fact-Book-2017.pdf, accessed May 16, 2017.

11 From ICBC Annual Report 2014, p. 10, retrieved at: http://www.icbc.com/about-icbc/company-info/ Documents/ar14.pdf.

12 Notice this it was not necessary to deflate these numbers for table 2 as both the numerator and denominator were monetary amounts. CPI All Items, 2011=100 (2011 is the base year) was employed.

13 K. F. Kennedy "A Case Study in Private Vs. Public Enterprise: The Manitoba Experience with Automobile Insurance", PhD thesis, 1976, University of Illinois at Urbana-Champaign, Business Administration. 


\section{APPENDIX TABLES}


TABLE A1a Mandated Policy for Private Provinces

\begin{tabular}{|c|c|c|c|c|c|c|}
\hline BENEFITS & ALBERTA & ONTARIO & NEW BRUNSWICK & NOVA SCOTIA & $\begin{array}{l}\text { NEWFOUNDLAND } \\
\text { AND LABRADOR }\end{array}$ & $\begin{array}{l}\text { PRINCE EDWARD } \\
\text { ISLAND }\end{array}$ \\
\hline $\begin{array}{l}\text { Mandatory Minimum } \\
\text { Third-party Liability }\end{array}$ & $\begin{array}{l}\$ 200,000 \text { available } \\
\text { for any one accident. } \\
\text { For claims involving } \\
\text { both bodily injury and } \\
\text { property damage, claim } \\
\text { for property damage } \\
\text { capped at } \$ 10,000 \text {. }\end{array}$ & $\begin{array}{l}\$ 200,000 \text { available } \\
\text { for any one accident. } \\
\text { For claims involving } \\
\text { both bodily injury and } \\
\text { property damage, claim } \\
\text { for property damage } \\
\text { capped at } \$ 10,000 \text {. }\end{array}$ & $\begin{array}{l}\$ 200,000 \text { available for } \\
\text { any one accident. For } \\
\text { claims involving both } \\
\text { bodily injury and property } \\
\text { damage, claim for } \\
\text { property damage capped } \\
\text { at } \$ 20,000 \text {. }\end{array}$ & $\begin{array}{l}\$ 500,000 \text { available for } \\
\text { any one accident. }\end{array}$ & $\begin{array}{l}\$ 200,000 \text { available } \\
\text { for any one accident. } \\
\text { For claims involving } \\
\text { both bodily injury and } \\
\text { property damage, claim } \\
\text { for property damage } \\
\text { capped at } \$ 20,000 \text {. }\end{array}$ & $\begin{array}{l}\$ 200,000 \text { available } \\
\text { for any one accident. } \\
\text { For claims involving } \\
\text { both bodily injury and } \\
\text { property damage, claim } \\
\text { for property damage } \\
\text { capped at } \$ 10,000 \text {. }\end{array}$ \\
\hline $\begin{array}{l}\text { Medical, Rehabilitation } \\
\text { and Attendant care }\end{array}$ & Up to $\$ 50,000 /$ person. & $\begin{array}{l}\text { Up to } \$ 3,500 \text { for minor } \\
\text { injury. Up to } \$ 65000 / \\
\text { person for non-minor } \\
\text { and non- catastrophic } \\
\text { injuries. Up to } \$ 1 \text { million } \\
\text { for catastrophic injury. }\end{array}$ & $\begin{array}{l}\text { Up to } \$ 50,000 / \text { person; } \\
\text { four-year time limit. }\end{array}$ & $\begin{array}{l}\text { Up to } \$ 50,000 / \text { person; } \\
\text { four-year time limit } \\
\text { (Consumers have } \\
\text { option to purchase } \\
\text { additional coverage). }\end{array}$ & $\begin{array}{l}\text { (Optional to buy) } \\
\text { Up to } \$ 25,000 / \text { person; } \\
\text { four-year time limit. }\end{array}$ & $\begin{array}{l}\text { Up to } \$ 50,000 / \text { person; } \\
\text { four-year time limit. }\end{array}$ \\
\hline Funeral Expenses & Up to $\$ 5,000$. & $\begin{array}{l}\text { Up to } \$ 6000 \text {. (Amount } \\
\text { may be higher if } \\
\text { optional indexation } \\
\text { coverage is } \\
\text { purchased). }\end{array}$ & Up to $\$ 2,500$. & Up to $\$ 2,500$. & $\begin{array}{l}\text { (Optional to buy) } \\
\text { Up to } \$ 1,000 \text {. }\end{array}$ & Up to $\$ 2,500$. \\
\hline
\end{tabular}

\section{Disability Income Benefits:}

\begin{tabular}{|c|c|c|c|}
\hline Income Replacement & $\begin{array}{l}80 \% \text { of gross weekly } \\
\text { wages to maximum } \\
\$ 400 / \text { week; } 104 \text { weeks } \\
\text { for total disability. }{ }^{*}\end{array}$ & $\begin{array}{l}70 \% \text { of gross wages to } \\
\text { maximum } \$ 400 / \text { week } \\
\text { for } 104 \text { weeks (longer } \\
\text { if victim is unable to } \\
\text { pursue any suitable } \\
\text { occupation).* }\end{array}$ & $\begin{array}{l}\text { Maximum } \\
\$ 250 / \text { week; } 104 \\
\text { weeks for partial } \\
\text { disability, lifetime for } \\
\text { total disability. Must be } \\
\text { disabled for at least } \\
\text { seven days to qualify. }\end{array}$ \\
\hline
\end{tabular}

Maximum \$250/week; 104 weeks for partial disability, lifetime for total disability; must be disabled for at least seven days to qualify.

\section{(Optional to buy)} Up to $\$ 140 /$ week; 104 weeks for partial disability; lifetime for total disability; must be disabled for at least seven days to qualify.
Maximum \$250/week; 104 weeks for partial disability, lifetime for total disability; must be disabled for at least seven days to qualify. 


\begin{tabular}{|c|c|c|c|c|c|c|}
\hline BENEFITS & ALBERTA & ONTARIO & NEW BRUNSWICK & NOVA SCOTIA & $\begin{array}{l}\text { NEWFOUNDLAND } \\
\text { AND LABRADOR }\end{array}$ & $\begin{array}{l}\text { PRINCE EDWARD } \\
\text { ISLAND }\end{array}$ \\
\hline Non-earners & $\begin{array}{l}\text { \$135/week, up to } 26 \\
\text { weeks. }\end{array}$ & $\begin{array}{l}\text { \$185/week for } \\
104 \text { weeks; 4-week } \\
\text { wait; limit two years. } \\
\text { (See Note 1). }\end{array}$ & N/A & $\mathrm{N} / \mathrm{A}$ & $\mathrm{N} / \mathrm{A}$ & $\mathrm{N} / \mathrm{A}$ \\
\hline Homemaker & N/A & $\begin{array}{l}\$ 100 / \text { week up to } \\
104 \text { weeks. }\end{array}$ & $\begin{array}{l}\$ 100 / \text { week up to } \\
52 \text { weeks. }\end{array}$ & $\begin{array}{l}\$ 100 / \text { week up to } \\
52 \text { weeks. }\end{array}$ & $\begin{array}{l}\$ 70 / \text { week, up to } \\
12 \text { weeks. }\end{array}$ & $\begin{array}{l}\$ 100 / \text { week up to } \\
52 \text { weeks. }\end{array}$ \\
\hline
\end{tabular}

\section{Death Benefits}

\section{Surviving Spouse}

Death of head of household: $\$ 10,000$, plus 20\% $(\$ 2,000)$ for each dependent survivor after first, plus additional $\$ 15,000$ for first survivor and $\$ 4,000$ for each remaining survivor: Death of spouse/adult interdependent partner of head of household $\$ 10,000$

Death of head of household: $\$ 10,000$ plus 20\% (\$2,000) for each dependent survivor after first, plus additiona $\$ 15,000$ for first survivo and $\$ 4,000$ for each remaining survivor; Death of spouse/adult interdependent partner of head of household $\$ 10,000$.
Death within 180 days of Death within 180 days accident (or three years (or two years if if continuously disabled continuously disabled prior to death); $\$ 25,000$ prior to death) of: minimum. (Amount may Head of household, be higher if optional indexation coverage is purchased). $\$ 50,000$ plus $\$ 1,000$ to each dependent after first; Spouse/partner, $\$ 25,000$.

Death within 180 days of Death within 180 days accident (or three years (or two years if if continuously disabled prior to death); $\$ 10,000$ each. (Amount may be higher if optional indexation coverage is purchased).

continuously disabled prior to death) of: Head of household, $\$ 50,000$ plus $\$ 1,000$ to each dependent after first; Spouse/partner, $\$ 25,000$$$
\$ 25,000 \text {. }
$$

Death within 180 days (or two years if continuously disabled prior to death) of: Head of household $\$ 25,000$ plus $\$ 1,000$ to each dependent after first. Spouse/partner $\$ 25,000$.

Death within 180 days (or two years if continuously disabled prior to death) of: Head of household $\$ 25,000$ plus $\$ 1,000$ to each dependent after first. Spouse/partner $\$ 25,000$.

\section{(Optional to buy)}

Death within 180 days (or two years if continuously disabled prior to death) of: Head of household, $\$ 10,000$, plus $\$ 1,000$ to each dependent survivor after first; Spouse, $\$ 10,000$.

(Optional to buy) Death within 180 days (or two years if continuously disabled prior to death) of: Head of household, $\$ 10,000$, plus $\$ 1,000$ to each dependent survivor after first; Spouse, $\$ 10,000$.
Death within 180 days (or two years if continuously disabled prior to death) of: Head of household $\$ 50,000$ plus $\$ 1,000$ to each dependent after first; Spouse/partner $\$ 25,000$.

Death within 180 days (or two years if continuously disabled prior to death) of: Head of household $\$ 50,000$ plus $\$ 1,000$ to each dependent after first: Spouse/partner \$25,000.

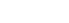




\begin{tabular}{|c|c|c|c|c|c|c|}
\hline BENEFITS & ALBERTA & ONTARIO & NEW BRUNSWICK & NOVA SCOTIA & $\begin{array}{l}\text { NEWFOUNDLAND } \\
\text { AND LABRADOR }\end{array}$ & $\begin{array}{l}\text { PRINCE EDWARD } \\
\text { ISLAND }\end{array}$ \\
\hline No Dependent & N/A & $\begin{array}{l}\$ 10,000 \text { per survivor. } \\
\text { (Amount may be } \\
\text { higher if optional } \\
\text { indexation coverage } \\
\text { is purchased). }\end{array}$ & N/A & N/A & N/A & N/A \\
\hline Parent/Guardian & $\begin{array}{l}\text { Death of dependent } \\
\text { relative: according to } \\
\text { age, maximum } \$ 3,000 \text {. }\end{array}$ & $\$ 10,000$ per survivor. & $\begin{array}{l}\text { Death within } 180 \text { days } \\
\text { (or two years if } \\
\text { continuously disabled } \\
\text { prior to death) of } \\
\text { dependant, } \$ 5,000 \text {. }\end{array}$ & $\begin{array}{l}\text { Death within } 180 \text { days } \\
\text { (or two years if } \\
\text { continuously disabled } \\
\text { prior to death) of } \\
\text { dependant } \$ 5,000 \text {. }\end{array}$ & $\begin{array}{l}\text { (Optional to buy) Death } \\
\text { within } 180 \text { days (or two } \\
\text { years if continuously } \\
\text { disabled prior to death) } \\
\text { of dependant } \$ 2,000 \text {. }\end{array}$ & $\begin{array}{l}\text { Death within } 180 \text { days } \\
\text { (or two years if } \\
\text { continuously disabled } \\
\text { prior to death) of } \\
\text { dependant } \$ 5,000 \text {. }\end{array}$ \\
\hline $\begin{array}{l}\text { Right to sue for pain } \\
\text { and suffering? }\end{array}$ & $\begin{array}{l}\text { Yes. If injury is deemed } \\
\text { "minor" under provincial } \\
\text { legislation, maximum } \\
\text { award is } \$ 5,020 \text {. }\end{array}$ & $\begin{array}{l}\text { Yes, if injury meets } \\
\text { severity test (called } \\
\text { "threshold"), and subject } \\
\text { to deductible. (See } \\
\text { Note 2). }\end{array}$ & $\begin{array}{l}\text { Yes. If injury is deemed } \\
\text { "minor" under provincial } \\
\text { legislation, maximum } \\
\text { award is } \$ 7,818.87 \text {. }\end{array}$ & $\begin{array}{l}\text { Yes. If injury is deemed } \\
\text { "minor" under provincial } \\
\text { legislation, maximum } \\
\text { award is } \$ 8,486 \text {. }\end{array}$ & $\begin{array}{l}\text { Yes. Awards are subject } \\
\text { to deductible of } \$ 2,500 \text {. }\end{array}$ & $\begin{array}{l}\text { Yes. If injury is deemed } \\
\text { "minor" under provincial } \\
\text { regulation, maximum } \\
\text { award is } \$ 7,545 \text {. }\end{array}$ \\
\hline $\begin{array}{l}\text { Right to sue for } \\
\text { economic loss in excess } \\
\text { of no-fault benefits? }\end{array}$ & Yes & Yes. (See Note 3). & Yes & Yes. & Yes. & Yes. \\
\hline
\end{tabular}

\section{Sources}

- Automobile Accident Insurance Benefits Regulations, accessed at: www.qp.alberta.ca/1266.cfm?page=1972_352.cfm\&leg_type=Regs\&isbncln=0779751140;

- Alberta Standard Automobile Policy, S.P.F. No. 1, accessed at: http://www.finance.alberta.ca/publications/insurance/automobile-insurance/policies-forms-certificates/

SPF1- Standard-Automobile-Policy-2013.pdf;

- Alberta Superintendent of Insurance Bulletin 07-2016, accessed at: http://www.finance.alberta.ca/publications/insurance/bulletins-notices/2016/Superintendent-of-Insurance- 2016-07-Bulletin.pdf;

- Alberta Superintendent of Insurance Bulletin 05-2015, accessed at: http://www.finance.alberta.ca/publications/insurance/bulletins-notices/2015/Superintendent-of-Insurance- 2015-05-Bulletin.pdf;

- Alberta Superintendent of Insurance Bulletin 11-2014, accessed at: http://www.finance.alberta.ca/publications/insurance/bulletins-notices/2014/Superintendent-of-Insurance- 2014-11-Bulletin.pdf;

- New Brunswick Standard Owner's Policy N.B.P.F. No.1, accessed at: http://0101.nccdn.net/1_5/1c2/1a0/1a9/StandardOwnersPolicy.pdf (Effective October 1, 2010); Injury Regulation, NB Reg 2003-20, accessed at: www.canlii.org/en/nb/laws/regu/nb-reg-2003-20/106597/nb-reg-2003-20.html;

- Financial and Consumer Services Commission. Notice Re: Annual Indexation PDF, accessed at: http://0104.nccdn.net/1_5/156/05b/0a6/January-2017-Annual-Indexation- Notice.pdf;

- Financial and Consumer Services Commission: Automobile Insurance, accessed at: http://fcnb.ca/automobile-insurance.html; 
- Automobile Insurance Act, Chapter A-22, an Act Respecting Automobile Insurance, accessed at: http://assembly.nl.ca/Legislation/sr/statutes/a22.htm; Newfoundland \& Labrador Standard Automobile Policy S.P.F. No.1 (not available online);

- Newfoundland \& Labrador Standard Automobile Policy S.P.F. No.1 (not available online)

- Nova Scotia Standard Automobile Policy NSPF No.1, 2013, accessed at: www.novascotia.ca/finance/site-finance/media/finance/SPF1-64103-01_2013.pdf; Automobile Insurance Contract Mandatory Conditions Regulations, accessed at: www.novascotia.ca/just/regulations/regs/imandcon.htm;

- Office of the Superintendent of Insurance Bulletin: Minor Injury Cap, accessed at: http://www.novascotia.ca/finance/site-finance/media/finance/Cap_Bulletin-Jan_2017.pdf; Ontario Automobile Policy, accessed at: www.fsco.gov.on.ca/en/auto/forms/Documents/OAP-1-Application-and-Endorsement-Forms/1215E.1.pdf;

- Statutory Accident Benefits Schedule (SABS), Insurance Act, 0. Reg. 34/10, accessed at: accessed at: www.e-laws.gov.on.ca/html/regs/english/elaws_regs_100034_e.htm; Financial Services Commission of Ontario: Auto Bulletins, accessed at: www.fsco.gov.on.ca/en/auto/autobulletins/Pages/default.asp

- Insurance Act, RSPEl 1988, c I-4, accessed at: www.gov.pe.ca/law/statutes/pdf/i-04.pdf;

- Prince Edward Island Standard Automobile Policy S.P.F. No.1, for accidents occurring on or after October 1, 2014, accessed at: www.gov.pe.ca/photos/original/ELJ_SampleAuto.pdf;

- Prince Edward Island Standard Automobile Policy S.P.F. No.1, for accidents occurring on or after October 1, 2015, accessed at: www.gov.pe.ca/photos/original/JPS_SampleAuto.pdf;

- Bill 46, An Act to Amend the Insurance Act (No. 2) (Chapter 36), accessed at: http://www.assembly.pe.ca/bills/pdf_chapter/64/4/chapter-36.pdf

- Office of Superintendent of Insurance Bulletin: Automobile Insurance Minor Injury Cap - Indexation, accessed at: http://www.gov.pe.ca/photos/original/MinlnjCap2017.pdf; October 1, 2015, Automobile Insurance Reforms, accessed at: www.gov.pe.ca/photos/original/JPS_InsReform.p

- Prince Edward Island Superintendent of Insurance—Notices, accessed at: www.gov.pe.ca/jps/index.php3?number=1053687\&lang=E.

\section{Notes}

* Nothing for first seven days of disability.

${ }^{* *}$ Nothing for first seven days of disability unless catastrophically injured.

1. For Ontario the "Non-Earners Benefit" is not available if the insured is eligible for, and elects to receive, the income replacement or caregiver benefit; Income replacement award above no-fault benefit is based on net income after deductions for income tax, Canada Pension and Employment Insurance.

2. Lawsuit allowed only if injured person dies or sustains permanent and serious disfigurement and/or impairment of important physical, mental or psychological function. The court assesses damages and deducts $\$ 36,905$ (\$18,453 for a Family Law Act claim).

3. Injured person may sue for $70 \%$ of net income loss before trial, $100 \%$ of gross after trial; also for medical, rehabilitation and related costs when injury meets severity test for pain and suffering claims. 
TABLE A1b Mandated Policy for Public Provinces

BENEFITS

Mandatory Minimum

Third-party Liability
BRITISH COLUMBIA

$\$ 200,000$ available for any one accident. For claims involving both bodily injury and property damage, property damage will be capped at $\$ 20,000$.

Medical, Rehabilitation
and Attendant care

and Attendant care

\begin{tabular}{l|l} 
& \\
\hline Funeral Expenses & Up to $\$ 2,500$
\end{tabular}

Disability Income

\section{Income Replacement}

$75 \%$ of gross weekly wages to maximum $\$ 300 /$ week;

104 weeks for temporary disability; lifetime for total disability. ${ }^{*}$

\begin{tabular}{|c|c|}
\hline Non-earners & N/A \\
\hline Homemaker & $\$ 145 /$ week, up to 104 weeks \\
\hline
\end{tabular}

\section{SASKATCHEWAN}

$\$ 200,000$ available for any one accident. For claims involving both bodily injury and property damage, property damage will be capped at $\$ 10,000$

\section{MANITOBA}

$\$ 200,000$ available for any one accident. For claims involving both bodily injury and property damage property damage will be capped at $\$ 20,000$.

\section{If no-fault option selected: If tort option selected:} Up to $\$ 6,813,680 /$ person. $\quad$ Up to $\$ 26,667 /$ person for non-catastrophic injury; Up to $\$ 200,000 /$ person for catastrophic injury.

Up to $\$ 10,219$.

Up to $\$ 6,667$.

$90 \%$ of net income based on gross annual income of maximum $\$ 94,587 /$ year. $^{* \star}$

After 180 days, will receive at least minimum wage if still disabled.

After 180 days, will receive at least minimum wage if still disabled. \$429/week for total disability; \$214/week for partial disability up to two years; maximum $\$ 22,308 /$ year

\$429/week for total disability; \$214/week for partial disability up to two years; maximum \$22,308/year.

\$429/week for total disability;

\$214/week for partial disability up to two years; maximum \$22,308/year.
$90 \%$ of net wages based on gross annual income of maximum $\$ 94,500 /$ year. ${ }^{*}$

After 180 days, will receive at least minimum wage.

No time or amount limit.

Up to $\$ 8,409$.

N/A
Up to $\$ 5,178$.

$90 \%$ of net wages based on gross annual income of maximum $\$ 72,500 /$ year; indexed.*

After 180 days, will receive at least minimum wage.

$\$ 50,000$ available for any one accident; liability limits ate to property damage

claims within Quebec and to age claims outside Quebec.

No time or amount limit. 


\section{Death Benefits}

Surviving Spouse

Death following a collision

of: Head of household

$\$ 5,000$, plus $\$ 145 /$ week

up to 104 weeks; Partner/

Spouse of head of household

$\$ 2,500$, plus $\$ 145 /$ week up

to 104 weeks.

Surviving Dependent

Death following a collision of: Head of household $\$ 1,000$ plus $\$ 35 /$ week up to 104 weeks to each child; Partner/ Spouse of head of household: $\$ 2,500$, plus $\$ 145 /$ week up to 104 weeks to each child.

\begin{tabular}{l|l} 
No Dependent & N/A \\
\hline Parent/Guardian & $\begin{array}{l}\text { Death following a collision of } \\
\text { dependent child: according to } \\
\text { age, maximum } \$ 1,500 .\end{array}$
\end{tabular}

age, maximum $\$ 1,500$.

\begin{tabular}{|c|c|c|}
\hline $\begin{array}{l}45 \% \text { of deceased's net } \\
\text { income to a maximum gross } \\
\text { salary of } \$ 94,587 \text { per year. }\end{array}$ & $\begin{array}{l}45 \% \text { of deceased's net } \\
\text { income to a maximum gross } \\
\text { salary of } \$ 94,587 \text { per year. }\end{array}$ & $\begin{array}{l}\text { Death any time after injury: } \\
\text { Depends on wage and age } \\
\text { of deceased and range from } \\
\$ 61,706 \text { to } \$ 472,500 \text {. }\end{array}$ \\
\hline $\begin{array}{l}5 \% \text { of the deceased's net } \\
\text { income per dependent child. }\end{array}$ & $\begin{array}{l}5 \% \text { of the deceased's net } \\
\text { income per dependent child. }\end{array}$ & $\begin{array}{l}\text { Death any time after injury: } \\
\text { Depends on the dependant's } \\
\text { age at time of accident } \\
\text { and range from } \$ 29,309 \text { to } \\
\$ 53,993 \text {, plus } \$ 26,995 \text { for a } \\
\text { disabled dependent. }\end{array}$ \\
\hline $\begin{array}{l}\$ 15,620 \text { maximum per } \\
\text { survivor/estate; } \$ 70,293 \\
\text { maximum total payable. }\end{array}$ & Up to $\$ 13,333$ to estate. & $\begin{array}{l}\text { Death any time after injury: } \\
\text { Up to } \$ 13,741 \text { per survivor. }\end{array}$ \\
\hline $\begin{array}{l}\text { Death of dependent child: } \\
\$ 31,240 \text {. }\end{array}$ & N/A & $\mathrm{N} / \mathrm{A}$ \\
\hline $\begin{array}{l}\text { Up to } \$ 195,257 \text { /person for } \\
\text { non-catastrophic injury and } \\
\text { up to } \$ 238,479 / \text { person for } \\
\text { catastrophic injury. }\end{array}$ & $\begin{array}{l}\text { Up to } \$ 13,333 / \text { person for } \\
\text { non-catastrophic injury; } \\
\text { Up to } \$ 173,333 / \text { person for } \\
\text { catastrophic injury. }\end{array}$ & $\begin{array}{l}\text { Minimum } \$ 770 / \text { week } \\
\text { up to } \$ 154,261 \text { for non- } \\
\text { catastrophic injury; Up to } \\
\$ 243,580 \text { for catastrophic } \\
\text { injury. }\end{array}$ \\
\hline
\end{tabular}

Death any time after accident: Benefits depend on gross annual income multiplied by a factor between one and five, depending on age of the victim; range from $\$ 69,102$ to $\$ 362,500$.

Death any time after accident: Benefits depend on dependent child's age; Range from $\$ 32,822$ to $\$ 60,466$.

Death any time afte accident: If there is no surviving spouse/dependant, parents or estate receive $\$ 55,386$.

Death any time after accident: If there is no surviving spouse/dependant, parents or estate receive $\$ 55,386$.

Up to $\$ 242,311$. 


\begin{tabular}{l|l|l|l|l|l}
\hline $\begin{array}{l}\text { Right to sue for pain } \\
\text { and suffering? }\end{array}$ & Yes & Yes & $\begin{array}{l}\text { Yes, subject to deductible } \\
\text { of } \$ 5,000 .\end{array}$ & No & No \\
\hline $\begin{array}{l}\text { Right to sue for } \\
\text { economic loss in excess } \\
\text { of no-fault benefits? }\end{array}$ & Yes & Yes & Yes & Yes & No \\
\hline
\end{tabular}

\section{Sources}

- ICBC Autoplan Insurance, accessed at: http://www.icbc.com/autoplan/Documents/autoplan-insurance.pdf; Guide to Autopac, accessed at: http://www.mpi.mb.ca/en/PDFs/PolicyGuide2017.pdf;

- Basic Personal Injury Protection Plan (PIPP) Benefits, accessed at: https://www.mpi.mb.ca/en/Claims/B//Pages/benefits.aspx; Services and Support Guide for Fatality Claims, accessed at: https://www.mpi. mb.ca/en/PDFs/SupportGuideFatalityClaims.pdf; SGl Canada Personal Injury Coverage, accessed at: https://www.sgi.sk.ca/individuals/registration/personalautoinjury/;

- Your Guide to No Fault Coverage, 2017, accessed at: https://www.sgi.sk.ca/pdf/guide_nofault_2017.pdf; Your Guide to Tort Coverage, 2017, accessed at: https://www.sgi.sk.ca/pdf/guide_tort_2017.pdf;

- SGI Auto Pak Policy booklet, 2017, accessed at: http://www.sgicanada.ca/sk/pdf/booklets/2017_auto_pak.pdf;

- Quebec Auto Insurance Policy Form Q.P.F. No.1, March 1, 2014, accessed at: https://lautorite.qc.ca/fileadmin/lautorite/professionnel//formulaires-professionnels/assureur/automobile/qpf_1.pdf

- The Insurance Policy for All Quebecers: Accident Victim, accessed at: www.saaq.gouv.qc.ca/en/accident_victim/insurance_policy/index.php Calculation of Death Benefits, 2017, accessed at: www.saaq.gouv.qc.ca/en/accident_victim/insurance_policy/death_table.php;

- IBC Fact Book 2017, http://assets.ibc.ca/Documents/Facts\%20Book/Facts_Book/2017/Fact-Book-2017.pdf.

\section{Notes}

* Nothing for first seven days of disability.

${ }^{\star *}$ Nothing for first seven days of disability unless catastrophically injured. 
TABLE A2 Factors Affecting Insurance Prices by Province

\begin{tabular}{|c|c|c|c|c|c|c|c|c|c|c|}
\hline \multirow[b]{2}{*}{ CRITERIA } & \multicolumn{6}{|c|}{ PRIVATE } & \multicolumn{4}{|c|}{ PUBLIC } \\
\hline & $A B$ & ON & NB & NS & PEI & NL & BC & SK & MB & QC \\
\hline \multicolumn{11}{|l|}{ Personal Profile } \\
\hline Age & Yes & Yes & No & No & Yes & No & No & No & No & Public: No; Private: Yes \\
\hline Marital Status & Yes & Yes & No & No & * & No & No & No & No & Public: No; Private: * \\
\hline Gender & Yes & Yes & No & Yes & * & No & No & No & No & Public: No; Private: Yes \\
\hline Driving Record & Yes & Yes & Yes & Yes & Yes & Yes & Yes & Yes & Yes & Yes \\
\hline Claim record of Policy Holder & Yes & Yes & Yes & Yes & Yes & Yes & Yes & Yes & Yes & Yes \\
\hline \multicolumn{11}{|l|}{ Vehicle } \\
\hline Make, Model and Year of Vehicle & Yes & Yes & Yes & Yes & Yes & Yes & Yes & Yes & Yes & Yes \\
\hline Rate Class & Yes & Yes & Yes & Yes & Yes & Yes & Yes & Yes & Yes & Yes \\
\hline Territory & Yes & Yes & Yes & Yes & Yes & Yes & Yes & No & Yes & Yes \\
\hline
\end{tabular}

Optional Coverage

Optional Coverage

Amount of Deductible Paid

Discounts and Savings

\begin{tabular}{c|c|c|c|c|c} 
Yes & Yes & Yes & Yes & Yes & Yes \\
Yes & Yes & Yes & Yes & Yes & Yes \\
\hline Yes & Yes & Yes & Yes & Yes & Yes
\end{tabular}

\begin{tabular}{|c|c|} 
Yes & Yes \\
Yes & Yes \\
\hline Yes & Yes
\end{tabular}

\begin{tabular}{c|c|} 
Yes \\
Yes \\
Yes & \\
\hline
\end{tabular}

Yes

Yes

\section{Sources}

- Age Rating in Auto Insurance, Actuarial Equity or Unfair Discrimination? (2007), accessed at: http://www.contingencies.org/septoct07/age.pdf; Alberta AlRB Factors that Affect Premiums, accessed at: http://www.airb.alberta.ca/drivers/factors.aspx;

- Alberta AlRB Ways to Lower Your Premium, accessed at: http://www.airb.alberta.ca/drivers/ways_to_lower.aspx; How has your Alberta auto insurance premium been determined, accessed at:

- http://www.melochemonnex.com/car-insurance/articles/autoinfo-alberta; 
- ICBC Autoplan Insurance Guide (For policies with an effective date before Sept. 11, 2016), accessed at: http://www.icbc.com/autoplan/Documents/autoplan-insurance.pdf; ICBC Autoplan Insurance, What Affects Your Autoplan Premium? accessed at: http://www.icbc.com/autoplan/costs/Pages/Default.aspx;

- MPI Guide to Autopac 2017 (Effective March 1, 2017), accessed at: https://www.mpi.mb.ca/en/PDFs/PolicyGuide2017.pdf; Final Report on Public Automobile Insurance in New Brunswick - Appendix C, accessed at: http://www.gnb.ca/legis/business/committees/reports/2004auto/PDF/Appendix_A_J-e.pdf;

- NEW BRUNSWICK REGULATION 2004-139 under the Insurance Act (0.C. 2004-530), accessed at: https://www.canlii.org/en/nb/laws/regu/nb-reg-2004-139/latest/nb-reg-2004-139.html;

- Communication New Brunswick, Justice and Consumer Affairs, News Release: New auto insurance territories announced (07/07/11), accessed at: http://www.gnb.ca/cnb/news/jus/2007e0898ju.htm;

- News Releases Government of Newfoundland \& Labrador—Canada, Government Services: Province Recognized for One of the Lowest Auto Insurance Premiums in the Country, accessed at:

http://www.releases.gov.nl.ca/releases/2007/gs/0216n03.htm;

- ICBC Buying Auto Insurance: How Auto Insurance Premiums Are Calculated, accessed at: http://www.ibc.ca/nl/auto/buying-auto-insurance; A Consumer's Auto Insurance Guide 2nd Edition, accessed at:

- http://www.novascotia.ca/finance/site-finance/media/finance/AutolnsuranceGuideConsumer.pdf;

- Nova Scotia Insurance Review Board, Report: To the Governor in Council on a Study into the Use of Gender as a Rating Factor in Automobile Insurance in Nova Scotia (November 1, 2004), accessed at: https://nsuarb.novascotia.ca/sites/default/files/nsirbgenderstudy.pdf

- FSCO, How Your Auto Insurance Rates are Set, accessed at: https://www.fsco.gov.on.ca/en/auto/brochures/Pages/how-your-auto-insurance-rates-are-set.aspx;

- Prince Edward Island, Regulatory \& Appeals Commission, FAQ: Auto Insurance Regulation, accessed at: http://www.irac.pe.ca/document.aspx?file=faq/documents/auto-insurance-faq.asp,

- IBC An update from Prince Edward Island's home, Auto and Business Insurers 2015, accessed at: http://assets.ibc.ca/_Documents/Facts\%20Book/Industry_Updates/2015/PEI-SOI.pdf;

- 2014 Final Report on Public Automobile Insurance in New Brunswick - Appendix A, accessed at: http://www.gnb.ca/legis/business/committees/reports/2004auto/PDF/Appendix_A_J-e.pdf;

- Kanetix, Car insurance in Quebec: A two-pronged approach, accessed at: https://www.kanetix.ca/quebec-car-insurance-canada;

- Lowestrates.ca, Compare Car Insurance Quotes to Get the Lowest Rates in Saskatchewan, accessed at: http://www.lowestrates.ca/insurance/auto/Saskatchewan.

\section{Note}

${ }^{*}$ Not clear regarding effect of this factor on price. 


\section{TABLE A3 Components of the Complete Insurance Package and Minimum Possible Liability Limits}

\begin{tabular}{|c|c|c|c|c|}
\hline PROVINCE & $\begin{array}{l}\text { THIRD PARTY } \\
\text { LIABILITY }\end{array}$ & $\begin{array}{l}\text { COLLISION AND } \\
\text { COMPREHENSIVE } \\
\text { DEDUCTIBLES }\end{array}$ & $\begin{array}{l}\text { THIRD PARTY } \\
\text { LIABILITY }\end{array}$ & $\begin{array}{l}\text { COLLISION AND } \\
\text { COMPREHENSIVE } \\
\text { DEDUCTIBLES }\end{array}$ \\
\hline \multicolumn{5}{|l|}{ Private } \\
\hline Ontario (Toronto) & $1,000,000$ & No Coverage & $2,000,000$ & 500,500 \\
\hline Alberta (Calgary) & $1,000,000$ & No Coverage & $2,000,000$ & 500,500 \\
\hline Quebec (Montreal) & $1,000,000$ & No Coverage & $2,000,000$ & 500,500 \\
\hline NS (Halifax) & $1,000,000$ & No Coverage & $2,000,000$ & 500,500 \\
\hline PEI (Charlottetown) & $1,000,000$ & No Coverage & $2,000,000$ & 500,500 \\
\hline NB (Moncton) & $1,000,000$ & No Coverage & $2,000,000$ & 500,500 \\
\hline NL (St John’s) & $1,000,000$ & No Coverage & $2,000,000$ & 500,500 \\
\hline \multicolumn{5}{|l|}{ Public } \\
\hline Manitoba (Winnipeg) & 200,000 & 500,500 & $2,000,000$ & 200,200 \\
\hline $\begin{array}{l}\text { Saskatchewan } \\
\text { (Saskatoon) }\end{array}$ & 200,000 & 700,700 & $2,000,000$ & 200,200 \\
\hline $\begin{array}{l}\text { British Columbia } \\
\text { Vancouver) }\end{array}$ & 200,000 & No Coverage & $3,000,000$ & 300,300 \\
\hline
\end{tabular}

\section{Sources}

- MPI Insurance, accessed at: https://www.mpi.mb.ca/en/Reg-and-Ins/Insurance/Optional- Autopac/Pages/orv_additional_ coverage.aspx

- Basic plate insurance vs. Auto Pak, accesses at: https://www.sgicanada.ca/sk/individuals/autoextension/compare.html; SGI Canada Auto extension insurance, accessed at: https:/www.sgicanada.ca/sk/individuals/autoextension/index.html; Autoplan Insurance, Basic Coverage, accessed at: http://www.icbc.com/autoplan/basic/Pages/default.aspx;

- Autoplan Insurance, Optional Coverage: Accessed at: http://www.icbc.com/autoplan/optional/Pages/Default.aspx.

Note

Complete Coverage for the provinces includes: Changing the Comprehensive Deductibles and Collision Deductible amounts respectively; Increased Third-Party Liability Limits; Loss of Use coverage and Rental vehicle coverage (excluding Manitoba). 
TABLE A4a Insurance Price Quotes for Private Provinces: Good Record

\begin{tabular}{|c|c|c|c|c|c|c|c|c|}
\hline \multirow[b]{3}{*}{ COMPANY } & \multicolumn{4}{|c|}{ ALBERTA, CALGARY } & \multicolumn{4}{|c|}{ ONTARIO, TORONTO } \\
\hline & \multicolumn{2}{|c|}{ Basic Coverage } & \multicolumn{2}{|c|}{ Complete Coverage } & \multicolumn{2}{|c|}{ Basic Coverage } & \multicolumn{2}{|c|}{ Complete Coverage } \\
\hline & Female & Male & Female & Male & Female & Male & Female & Male \\
\hline **Lowest & 660 & 660 & 1,162 & 1,162 & 1,185 & 1,234 & 1,575 & 1,629 \\
\hline Unspecified & & & & & & 1,285 & & 1,727 \\
\hline Belairdirect & & & & & 1,958 & 1,855 & 2,309 & 2,194 \\
\hline CAA & & & & & 2,771 & 2,771 & 3,409 & 3,409 \\
\hline Coachman & & & & & 3,460 & 3,460 & 4,071 & 4,071 \\
\hline Echelon & & & & & 3,766 & 3,505 & 4,724 & 4,463 \\
\hline Economical & 669 & 667 & 1,337 & 1,345 & 1,671 & 1,848 & 2,143 & 2,354 \\
\hline Johnson Home-Auto & $698^{\star}$ & $698^{*}$ & $1,223^{*}$ & $1,223^{*}$ & 1,696 & 1,696 & 1,930 & 1,930 \\
\hline PAFCO & & & & & 3,948 & 3,948 & & \\
\hline Pembridge & 679 & 679 & 1,286 & 1,286 & 3,147 & 3,132 & 3,755 & 3,755 \\
\hline TD & 822 & 839 & 1,492 & 1,549 & 1,917 & 1,682 & 2,240 & 2,010 \\
\hline Travelers Dominion & & & & & 1,783 & 1,851 & 2,152 & 2,241 \\
\hline Wawanesa & & & & & 2,183 & 2,183 & 2,589 & 2,589 \\
\hline \multicolumn{9}{|l|}{ SSQauto } \\
\hline The Co-operators & $771^{*}$ & $771^{*}$ & $1,643^{*}$ & $1,683^{*}$ & 1,725 & 1,661 & 2,343 & 2,268 \\
\hline Allstate & 835 & 835 & 1,439 & 1,439 & 3,525 & 3,507 & 3,486 & 3,428 \\
\hline \multicolumn{9}{|l|}{ COSECO } \\
\hline Intact & 916 & 902 & 1,897 & 1,954 & 2,011 & 1,859 & 2,439 & 2,307 \\
\hline Millennium & & & 1,265 & 1,265 & & & & \\
\hline Desjardins & 978 & 866 & 1,610 & 1,517 & 1,406 & & 1,815 & \\
\hline Average & 796 & 782 & 1,466 & 1,473 & 2,464 & 2,497 & 2,815 & 2,848 \\
\hline
\end{tabular}


TABLE A4a continued: Insurance Price Quotes for Private Provinces: Good Record

\begin{tabular}{|c|c|c|c|c|c|c|c|c|c|c|c|c|c|c|c|c|}
\hline \multirow[b]{3}{*}{ COMPANY } & \multicolumn{4}{|c|}{ MONCTON, NB } & \multicolumn{4}{|c|}{ HALIFAX, NS } & \multicolumn{4}{|c|}{ CHARLOTTETOWN, PEI } & \multicolumn{4}{|c|}{ ST JOHNS, NL } \\
\hline & \multicolumn{2}{|c|}{$\begin{array}{c}\text { Basic } \\
\text { Coverage }\end{array}$} & \multicolumn{2}{|c|}{$\begin{array}{l}\text { Complete } \\
\text { Coverage }\end{array}$} & \multicolumn{2}{|c|}{$\begin{array}{c}\text { Basic } \\
\text { Coverage }\end{array}$} & \multicolumn{2}{|c|}{$\begin{array}{l}\text { Complete } \\
\text { Coverage }\end{array}$} & \multicolumn{2}{|c|}{$\begin{array}{c}\text { Basic } \\
\text { Coverage }\end{array}$} & \multicolumn{2}{|c|}{$\begin{array}{l}\text { Complete } \\
\text { Coverage }\end{array}$} & \multicolumn{2}{|c|}{$\begin{array}{c}\text { Basic } \\
\text { Coverage }\end{array}$} & \multicolumn{2}{|c|}{$\begin{array}{l}\text { Complete } \\
\text { Coverage }\end{array}$} \\
\hline & Female & Male & Female & Male & Female & Male & Female & Male & Female & Male & Female & Male & Female & Male & Female & Male \\
\hline **Lowest & 774 & 774 & 956 & 956 & 658 & 658 & 1,120 & 1,120 & 391 & 391 & 993 & 993 & & & & \\
\hline CAA & 802 & 802 & 1,214 & 1,214 & & & & & & & & & & & & \\
\hline Johnson Home-Auto & $587^{\star}$ & $587^{*}$ & $1,049^{\star}$ & $1,049^{\star}$ & $690^{\star}$ & $690^{\star}$ & $1,032^{*}$ & $1,032^{\star}$ & $606^{\star}$ & $606^{\star}$ & $1,017^{*}$ & $1,017^{*}$ & $918^{*}$ & $918^{*}$ & 1,329 & 1,329 \\
\hline TD & $745^{\star}$ & $745^{\star}$ & $1,085^{\star}$ & $1,085^{\star}$ & $653^{*}$ & $643^{*}$ & $1,114^{\star}$ & $1,123^{*}$ & $440^{*}$ & $439^{*}$ & $1,213^{*}$ & $1,258^{*}$ & $1,106^{\star}$ & $1,106^{*}$ & $1,791^{\star}$ & $1,791^{*}$ \\
\hline The Co-operators & $898^{*}$ & $898^{\star}$ & $1,349^{*}$ & $1,349^{\star}$ & $896^{\star}$ & $883^{\star}$ & $1,433^{*}$ & $1,421^{*}$ & $629^{\star}$ & $629^{*}$ & $1,062^{*}$ & $1,062^{*}$ & $1,751^{*}$ & $1,751^{*}$ & $2,377^{\star}$ & $2,377^{*}$ \\
\hline CAA Atlantic & $843^{*}$ & $843^{*}$ & $1,283^{\star}$ & $1,283^{*}$ & $658^{\star}$ & $658^{*}$ & $1,130^{\star}$ & $1,130^{\star}$ & $391^{*}$ & $391^{*}$ & $1,002^{*}$ & $1,002^{\star}$ & & & & \\
\hline Allstate & & & & & 924 & 924 & 1,162 & 1,162 & & & & & & & & \\
\hline COSECO & & & $1,099^{\star}$ & $1,099^{\star}$ & & & 1,146 & 1,190 & & & & & & & & \\
\hline Average & 775 & 775 & 1,180 & 1,180 & 764 & 760 & 1,170 & 1,176 & 517 & 516 & 1,074 & 1,085 & 1,258 & 1,258 & 1,832 & 1,832 \\
\hline
\end{tabular}

\section{Sources}


do not necessarily quote for all cities.

2. ${ }^{* \star}$ Kanetix provides a "lowest rate" but does not identify it until the consumer calls for a quote.

Notes

1. All quotes exclude the respective registration costs and any applicable taxes in each province.

2. "Average" excludes "lowest unspecified rate". 
TABLE 4Ab Insurance Price Quotes for Private Provinces: Poor Record

\begin{tabular}{|c|c|c|c|c|c|c|c|c|}
\hline \multirow[b]{3}{*}{ COMPANY } & \multicolumn{4}{|c|}{ ALBERTA, CALGARY } & \multicolumn{4}{|c|}{ ONTARIO, TORONTO } \\
\hline & \multicolumn{2}{|c|}{ Basic Coverage } & \multicolumn{2}{|c|}{ Complete Coverage } & \multicolumn{2}{|c|}{ Basic Coverage } & \multicolumn{2}{|c|}{ Complete Coverage } \\
\hline & Female & Male & Female & Male & Female & Male & Female & Male \\
\hline${ }^{* *}$ Lowest & 1,008 & 1,031 & 1,843 & 1,915 & 2,286 & 2,081 & 2,847 & 2,691 \\
\hline Belairdirect & & & & & 4,402 & 4,123 & 5,159 & 4,847 \\
\hline CAA & & & & & 6,572 & 6,572 & 7,809 & 7,809 \\
\hline Coachman & & & & & 4,749 & 4,749 & 5,512 & 5,512 \\
\hline Echelon & & & & & 5,243 & 4,979 & 6,408 & 6,144 \\
\hline Economical & 1,236 & 1,236 & 2,688 & 2,688 & 3,393 & 3,755 & 4,148 & 4,572 \\
\hline Johnson Home-Auto & 1,226 & 1,226 & 2,481 & 2,481 & & & & \\
\hline PAFCO & & & & & 4,482 & 4,482 & & \\
\hline Pembridge & 1,223 & 1,223 & 2,856 & 2,856 & 5,621 & 5,562 & 6,997 & 6,938 \\
\hline $\begin{array}{l}\text { Travelers Dominion } \\
\text { Product }\end{array}$ & & & & & 2,896 & 3,022 & 3,476 & 3,639 \\
\hline Wawanesa & & & & & 3,748 & 3,748 & 4,355 & 4,355 \\
\hline \multicolumn{9}{|l|}{ SSQauto } \\
\hline The Co-operators & & & & & 2,585 & 2,493 & 3,416 & 3,306 \\
\hline Intact & 1,216 & 1,216 & 2,594 & 2,682 & 4,528 & 4,190 & 5,307 & 5,003 \\
\hline Allstate & 1,216 & 1,216 & 2,862 & 2,991 & 6,370 & 6,298 & 7,802 & 7,730 \\
\hline Millennium & & & 2,496 & 2,496 & & & & \\
\hline Raptors Home+Auto & & & & & 2,538 & 2,634 & 3,149 & 3,255 \\
\hline Average & 1,223 & 1,223 & 2,663 & 2,699 & 4,394 & 4,354 & 5,295 & 5,259 \\
\hline
\end{tabular}




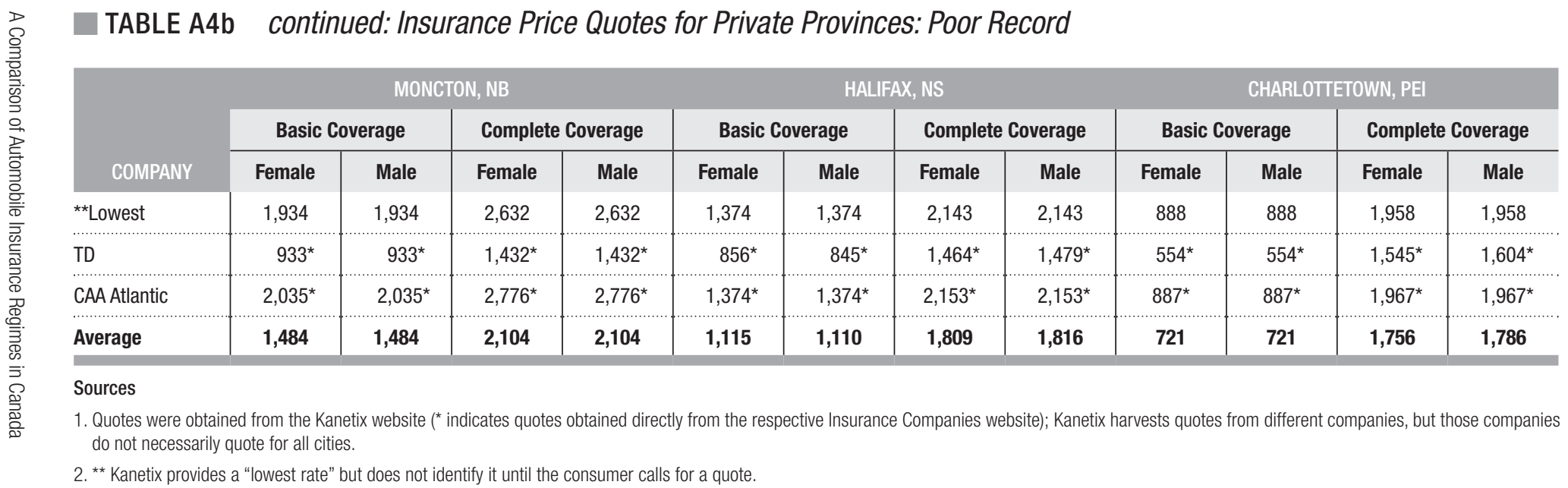

Notes

1. All quotes exclude the respective registration costs and any applicable taxes in each province.

2. "Average" excludes "lowest unspecified rate". 
TABLE A4c Insurance Price Quotes for Public Provinces: Good Record

\begin{tabular}{|c|c|c|c|c|c|c|}
\hline \multirow[b]{3}{*}{ COMPANY } & \multicolumn{2}{|c|}{ BRITISH COLUMBIA, VANCOUVER } & \multicolumn{2}{|c|}{ SASKATCHEWAN, SASKATOON } & \multicolumn{2}{|c|}{ MANITOBA, WINNIPEG } \\
\hline & Basic Coverage & Complete Coverage & Basic Coverage & Basic Coverage & Complete Coverage & Complete Coverage \\
\hline & ICBC Basic Autoplan & ICBC & SGI Basic Plate & ICBC Basic Autoplan & ICBC & MPI \\
\hline Manitoba Public Insurance & & & & & 1,167 & 1,451 \\
\hline Saskatchewan Government Insurance & & & 917 & 1,125 & & \\
\hline Affinity Insurance Services Inc Lakewood & & & 917 & 1,125 & & \\
\hline Affinity Insurance Services Inc Preston Ave. & & & 917 & 1,142 & & \\
\hline Life Line General Insurance Inc & & & 917 & 1,125 & & \\
\hline Hoffmann Kool Insurance & & & 917 & 1,135 & & \\
\hline Galon Insurance Brokers & & & 917 & 1,135 & & \\
\hline Westland Insurance Group Ltd & 1,089 & 1,618 & & & & \\
\hline Affinity Insurance Services & 1,072 & 2,372 & & & & \\
\hline Pemberton Insurance Corporation & 1,064 & 1,855 & & & & \\
\hline Hicks Pacific Centre Insurance Service Ltd & 1,123 & 1,848 & & & & \\
\hline BCAA & 1,089 & 1,620 & & & & \\
\hline Thompson Insurance Centre (1997) Inc & 1,082 & 1,807 & & & & \\
\hline Average & 1,087 & 1,853 & 917 & 1,131 & 1,167 & 1,451 \\
\hline
\end{tabular}

\section{Sources}

1. Manitoba Public Insurance (MPI) quotes where obtained from the MPI website.

2. Saskatchewan Government Insurance "(SGI) Basic Plate" quotes for Saskatchewan were obtained from the SGI website; The "SGI Autopak" quotes were obtained from the individual brokers listed in the table.

3. The ICBC Basic Autoplan and Optional Autoplan where both obtained from each individual broker listed.

Note

All quotes exclude the respective registration costs and any applicable taxes in each province. 
TABLE A4d Insurance Price Quotes for Public Provinces: Poor Record

\begin{tabular}{|c|c|c|c|c|c|c|}
\hline \multirow[b]{3}{*}{ COMPANY } & \multicolumn{2}{|c|}{ BRITISH COLUMBIA, VANCOUVER } & \multicolumn{2}{|c|}{ SASKATCHEWAN, SASKATOON } & \multicolumn{2}{|c|}{ MANITOBA, WINNIPEG } \\
\hline & Basic Coverage & Complete Coverage & Basic Coverage & Complete Coverage & Basic Coverage & Complete Coverage \\
\hline & $\begin{array}{l}\text { ICBC Basic } \\
\text { Autoplan }\end{array}$ & $\begin{array}{l}\text { ICBC Optional } \\
\text { Autoplan }\end{array}$ & SGI Basic Plate & SGI Autopak & MPI Basic Autopac & MPI Optional Autopac \\
\hline Manitoba Public Insurance & & & & & 1,239 & 1,541 \\
\hline Saskatchewan Government Insurance & & & 978 & & & \\
\hline Affinity Insurance Services Inc Lakewood & & & 978 & 1,236 & & \\
\hline Affinity Insurance Services Inc Preston Ave. & & & 978 & 1,253 & & \\
\hline Life Line General Insurance Inc & & & 978 & 1,207 & & \\
\hline Hoffmann Kool Insurance & & & 978 & 1,226 & & \\
\hline Galon Insurance Brokers & & & 978 & 1,226 & & \\
\hline Westland Insurance Group Ltd & 1,594 & 1,743 & & & & \\
\hline Affinity Insurance Services & 1,618 & 1,743 & & & & \\
\hline Pemberton Insurance Corporation & 1,514 & 2,640 & & & & \\
\hline Hicks Pacific Centre Insurance Service Ltd & 1,573 & 2,610 & & & & \\
\hline BCAA & 1,594 & 2,556 & & & & \\
\hline Thompson Insurance Centre (1997) Inc & 1,533 & 2,569 & & & & \\
\hline Averages & 1,571 & 2,310 & 978 & 1,230 & 1,239 & 1,541 \\
\hline
\end{tabular}

\section{Sources}

See Table A4c.

Note

o All quotes exclude the respective registration costs and any applicable taxes in each province. 


\section{TABLE A5 Sources for Tables 2 and 3 in text and Graph 2}

\section{Sources Tables 2 and 3:}

- 2015 GISA Automobile Exhibit Introduction, accessed at: https://www.gisa.ca/Statisticallnformation; 2015 GISA Actual Loss Ratio Exhibits, accessed at: https://www.gisa.ca/Statisticallnformation;

- 2009 to 2015 ICBC Annual Service Plan Reports, accessed at: http://www.icbc.com/about-icbc/company-info/ Pages/Annual-Report.aspx; 2008 ICBC Annual Service Plan Report, accessed at: http://www.fin.gov.bc.ca/ocg/ pa/08_09/Sup\%20E/pdf/ICBC_Fin_Stmts.pdf;

- ICBC Consolidated Financial Statements As At December 31, 2007, accessed at: http://www.fin.gov.bc.ca/ocg/ pa/07_08/Sup\%20E/pdf/ICBC_Fin_Stmts.pdf; ICBC Consolidated Financial Statements As At December 31, 2006, accessed at: http://www.fin.gov.bc.ca/ocg/pa/06_07/Sup\%20E/pdf/ICBC_Fin_Stmts.pdf;

- 2007 to 2015-16 Saskatchewan Auto fund Annual Reports, accessed at: https://www.sgi.sk.ca/about/ publications/index.html; 2007/2006 to 2016/15 MPI Annual Reports, accessed at: https://www.mpi.mb.ca/en/ Newsroom/Pages/annualreports.aspx;

- 2012/11 to 2016/15 MPI Annual Financial Statements, accessed at: https://www.mpi.mb.ca/en/Newsroom/ Pages/annualreports.aspx.

\section{Sources Graph 2:}

- 2010 to 2016 Ontario Road Safety Annual Report, accessed at: http://www.ontario.ca/orsar;

- 2002 to 2014 Alberta Collision Statistics, accessed at: http://www.transportation.alberta.ca/3119.htm;

- 2017 ICBC Quick Statistics for the Media, accessed at: http://www.icbc.com/about-icbc/newsroom/Pages/ Statistics.aspx; 2011 to 2016 ICBC Quick Statistics for the Media, accessed at: http://www.integritybc.ca/ ?page_id=6149;

- 2002 to 2007 ICBC Traffic Collision Statistics: Police-attended Injury and Fatal Collisions, accessed at: http://www.integritybc.ca/?page_id=6157;

- SAAQ Bilan 2015 - Accidents, parc automobile, permis de conduire, accessed at: https://saaq.gouv.qc.ca/ fileadmin/documents/publications/espace-recherche/dossier-statistique-bilan-2015.pdf;

- SAAQ Bilan 2016 - Accidents, parc automobile, permis de conduire, personal communication with E. Turmel (May 19, 2017); 2012 to 2015 MPI Traffic Collision Statistics Report, accessed at: https://www.mpi.mb.ca/en/ Rd- Safety/Overview/Pages/TrafficCollisionStatisticsReport.aspx;

- 2012 to 2015 SGI TAIS Annual Report, accessed at: https://www.sgi.sk.ca/about/publications/collisionstats/ index.html; 1999 to 2015: Statistics Canada, CANSIM Table 405-0004, Total Road Motor Vehicles. 